\title{
KOBIETY NA SZWEDZKIM RYNKU PRACY \\ - UWARUNKOWANIA WYSOKIEJ AKTYWNOŚCI ZAWODOWEJ I WYZWANIA NA PRZYSZŁOŚĆ
}

\section{Wprowadzenie}

Szwecja jest liderem w zapewnianiu równych szans kobiet i mężczyzn. Według raportu Światowego Forum Ekonomicznego „Gender Global Gap Report”, opracowywanego z uwzględnieniem sytuacji kobiet na rynku pracy, w edukacji, polityce i zdrowiu, Szwecja od lat zajmuje miejsce w pierwszej czwórce na 115-136 państw w zależności od roku ${ }^{1}$. Wynik ten jest konsekwencją świadomych działań w tym zakresie prowadzonych od kilku dziesięcioleci i pełnym odzwierciedleniem zasad szwedzkiego modelu państwa dobrobytu.

Opracowanie koncentruje się wokół pytania, jak Szwecji udało się osiągnąć najwyższe w Unii Europejskiej wskaźniki zatrudnienia kobiet i w jakich obszarach musi kontynuować wysiłki, by nie stracić tej pozycji. W pierwszej części, jako tło, zaprezentowano kilka zasadniczych cech szwedzkiego modelu, które stanowią kontekst dla szczegółowych decyzji Sztokholmu w zakresie wsparcia polityki godzenia życia zawodowego z rodzinnym Szwedek i Szwedów. Druga część to statystyczny obraz sytuacji kobiet i mężczyzn na szwedzkim rynku pracy na tle innych państw członkowskich potwierdzający wyjątkowość sytuacji kobiet. Analiza prowadzi do zasadniczych kwestii, będących próbą pokazania czynników, które decydują o skuteczności prowadzonej polityki, czyli tego, jak strategia państwa, wzorce kulturowe i funkcjonujące praktyczne mechanizmy wpływają na zwiększenie wskaźników zatrudnienia kobiet w Szwecji. Opracowanie kończy refleksja co do problemów pozostających do rozwiązania w zakresie m.in. wysokiego udziału kobiet $\mathrm{w}$ zatrudnieniu $\mathrm{w}$ niepełnym wymiarze czasu pracy, różnic $\mathrm{w}$ wynagrodzeniach

1 W latach 2006 i 2007 Szwecja zajmowała pierwsza pozycję w rankingu. W kolejnych latach do 2013 r. była na czwartej pozycji po Irlandii, Finlandii i Norwegii. Zob. Gender Global Gap Report 2013 Światowego Forum Ekonomicznego, http://reports.weforum.org/global-gender-gap-report-2013/, dostęp 9.03.2014. 
czy niewystarczającego zainteresowania mężczyzn wykorzystaniem urlopów rodzicielskich. Pominięto w nim natomiast aspekty ekonomiczne analizowanego problemu odnoszące się do tego, w jaki sposób czynniki ekonomiczne kształtują sytuację kobiet na szwedzkim rynku pracy i jak ich aktywność zawodowa wpływa na konkurencyjność gospodarki.

\section{Model nordycki² jako główny wyznacznik polityki}

Zgodnie z typologią podziału zaproponowaną przez Gostę Esping-Andersena Szwecja stanowi modelowy przykład państwa socjaldemokratycznego różniącego się w sposób zasadniczy od państw liberalnych i konserwatywnych. Kluczową rolę w wypełnianiu funkcji opiekuńczej w modelu socjaldemokratycznym pełni państwo w odróżnieniu od modelu liberalnego, w którym nadrzędny jest rynek, i konserwatywnego z główną rolą przypisywaną rodzinie. Ponadto cechuje go wysoki poziom dekomodyfikacji odnoszącej się do uniezależnienia sytuacji materialnej i dostępu do środków pieniężnych od sytuacji jednostki na rynku pracy. W państwach liberalnych ten poziom jest minimalny, z kolei w konserwatywnych jest wysoki, ale jedynie dla żywiciela rodziny. Na fali krytycyzmu pierwotnej propozycji Esping-Andersena, która nie uwzględniała roli rodziny, kwestii płci i nieodpłatnej pracy w państwach opiekuńczych, twórca typologii wprowadził dodatkowo koncepcję defamilizacji odnoszącej się do stopnia, w jakim państwo opiekuńcze lub rynek przejmują zadania wynikające z opieki nad rodziną. Proces ten ma jednocześnie wzmacniać rodzinę poprzez

2 Problematyka państw nordyckich, ich cech charakterystycznych, a także ewolucji na przestrzeni XX i XXI w. jest szeroko omówiona w licznych publikacjach. Szerzej zob. m.in.: W. Anioł, Szlak Norden. Modernizacja po skandynawsku, Warszawa 2013; W. Rutkowski, Współczesne państwo dobrobytu. Ekspansja, kryzys, spory, Warszawa 2009; W. Nowiak, Nordycki model „welfare state" w realiach XXI wieku. Dylematy wyboru i ewolucja systemu w społeczeństwach dobrobytu - wnioski praktyczne, Poznań 2011; S. Czech, Gospodarka w stużbie idei. Rzecz o modelu szwedzkim, Katowice 2013; J. Wiśniewski, Ewolucja szwedzkiego i brytyjskiego modelu polityki społecznej w latach 1993-2003, Warszawa 2005; S. Saxonberg, Model szwedzki ma się dobrze. Problemy polityki społecznej, „Studia i Dyskusje” 2004, nr 2; W. Rutkowski, Ewolucja szwedzkiego państwa dobrobytu, „Polityka Społeczna” 2005, nr 4; Y. Stryjan, Socjaldemokracja, rynek pracy i trzeci sektor - przypadek szwedzki, „Problemy Polityki Społecznej. Studia i Dyskusje” 2005, nr 8; T. Kowalik, Współczesne systemy ekonomiczne. Powstawanie, ewolucja, kryzys, Warszawa 2000; E. Wadensjö, Social insurance in Sweden: the Swedish model and its challenge in the $21^{\text {st }}$ century, w: Institutions for social well being: alternatives for Europe, red. L. Costabile, Palgrave Macmillan, Basingstoke, New York 2008; Reform and perspectives on social insurance: lessons from the East and West, red. M.-Ch. Kuo, H.F. Zacher, H.-S. Chan, Kluwer Law International, Hague, New York 2002; D. Anxo, H. Niklasson, The Swedish model: revival after the turbulent 1990 s?, w: European Employment Models in Flux. A comparison of Institutional Change in Nine European Countries, red. G. Bosh, S. Lehendorff, J. Rubery, Hampshire, New York 2009; W. Anioł, Skandynawskie państwo opiekuńcze - erozja czy reaktywacja?, „Analizy Norden Centrum” 2013, nr 8. 
zapewnienie wsparcia, które powodowałoby ulżenie jej obowiązkom, i zwiększać możliwości wyboru jej członkom. W państwach takich jak Szwecja i państwa modelu liberalnego poziom tego zjawiska jest wysoki w odróżnieniu od państw konserwatywnych. Tej ostatniej kwestii przypisuje się kluczowe znaczenie w zapewnieniu tak wysokiego udziału Szwedek w rynku pracy ${ }^{3}$.

Analizując kwestię zabezpieczenia społecznego, model skandynawski charakteryzuje 6 zasadniczych cech: 1) zapewnienie wysokiego poziomu bezpieczeństwa socjalnego, co oznacza, że w państwach tego modelu świadczenia mają charakter uniwersalny przysługujący z tytułu obywatelstwa; 2) środki budżetu państwa stanowią główne i hojne źródło finansowania usług publicznych;3) państwo jest głównym ich dostarczycielem i stanowi w konsekwencji istotny sektor zatrudnienia; 4) silna decentralizacja świadczenia usług wynikająca z ich szerokiego zakresu; 5) duże znaczenie świadczeń rzeczowych w porównaniu ze świadczeniami pieniężnymi; 6) poparcie społeczeństwa dla funkcji państwa i zakresu interwencji ${ }^{4}$.

Polityka w zakresie godzenia życia zawodowego z rodzinnym, kształtująca sytuację kobiet na rynku pracy, stanowi pochodną głównych zasad systemu państwa, w którym funkcjonuje, ewoluując jednocześnie w czasie. Do lat 50. XX w. politykę tę kształtowano w oparciu o tradycyjny model męskiego żywiciela - od mężczyzny oczekiwano utrzymania rodziny, od kobiety opieki nad dziećmi i zajęcia się domem. Skutkowało to zróżnicowanym podejściem do ubezpieczeń zdrowotnych, od bezrobocia czy wypadku przy pracy. W latach 30 . ubiegłego wieku pojawiły się problemy demograficzne, które spowodowały wprowadzenie nowej polityki rodzinnej, niemniej nadal koncentrującej się wokół tradycyjnego modelu. W pierwszej kolejności ustanowiono zabezpieczenie mężczyzny, na wypadek gdyby nie mógł on utrzymać rodziny, w następnej uwzględniono również matki. Jednocześnie wprowadzono powszechny zasiłek na dzieci wypłacany bezpośrednio matce. Tym samym z jednej strony wzmacniano dotychczasowy model, z drugiej pozycję kobiet. W latach 50. i 60. XX w. zgodnie z modelem szwedzkiego państwa opiekuńczego rozpoczęto konsekwentne i trwające do czasów współczesnych promowanie równouprawnienia kobiet i mężczyzn, które miało zostać osiągnięte poprzez zapewnienie kobietom dostępu do zatrudnienia. Miała temu sprzyjać możliwość zdobycia przez kobiety wykształcenia na poziomie wyższym, równość wynagrodzeń, sektor publiczny, który wraz

3 Zob. szerzej: W. Anioł, Szlak Norden..., op.cit., s. 32-34; L. den Dulk, A. van Doorne-Huiskes, Social policy in Europe: its impact on families and work, w: Women, men, work and family in Europe, red. R. Crompton, S. Lewis, C. Lyonette, Palgrave Macmillan, Basingstoke, New York 2007, s. 35-36.

4 W. Rutkowski, Współczesne państwo..., op.cit., s. 138. 
$\mathrm{z}$ rozwojem $\mathrm{w}$ tamtych latach generował głównie miejsca pracy postrzegane jako kobiece, a także system zinstytucjonalizowanej opieki nad dziećmi ${ }^{5}$.

\section{Sytuacja kobiet na rynku pracy w świetle statystyk}

Szwecja pozostaje liderem w Unii Europejskiej pod względem wskaźnika zatrudnienia kobiet (tabela 1). W latach 2000, 2006 i 2012 był on powyżej średniej unijnej i wykazywał stałą tendencję rosnącą do 2012 r., sięgając 76,8\%. Różnice względem średniej dla Unii Europejskiej ulegały zmniejszeniu, niemniej nadal przewyższają 14 pkt. proc. Powolnemu wzrostowi poziomu zatrudnienia kobiet w Szwecji towarzyszy minimalne zwiększenie różnic w poziomie zatrudnienia mężczyzn i kobiet. Jednocześnie różnice te są jednymi z najniższych w Unii Europejskiej, nie przekraczając $\mathrm{w}$ analizowanym okresie 6 pkt. proc. Takie wyniki w porównaniu z różnicami sięgającymi ponad 20 pkt. proc. w Grecji, we Włoszech i na Malcie we wszystkich analizowanych latach świadczą o możliwości osiągnięcia przez Szwecję równowagi w poziomie zatrudnienia ze względu na płeć.

Co do poziomu bezrobocia kobiet Szwecja traci pozycję lidera, niemniej nadal sytuacja jest korzystniejsza niż w większości państw członkowskich i średniej dla całej Unii Europejskiej (tabela 1). W 2012 r. poziom bezrobocia wśród Szwedek sięgał 7,7\% i był o 2,8 pkt. proc. niższy od średniej dla wszystkich członków UE. Jednocześnie różnica w porównaniu z Grecją, gdzie występował najwyższy poziom bezrobocia kobiet, to ponad 20 pkt. proc., a z Austrii, gdzie sytuacja była najkorzystniejsza, to 3,4 pkt. proc. Szwecja pozostaje również państwem o zbliżonym poziomie bezrobocia kobiet i mężczyzn. W analizowanym okresie mieściła się w grupie siedmiu państw o najniższych różnicach nieprzekraczających 0,6 pkt. proc. i jedynie w 2012 r. sytuacja w Szwecji była mniej korzystna niż w całej Unii Europejskiej. W odróżnieniu od poziomu zatrudnienia, w którego przypadku wskaźnik we wszystkich analizowanych latach i dla wszystkich państw członkowskich był korzystniejszy dla mężczyzn, w przypadku stopy bezrobocia sytuacja jest bardziej zróżnicowana zarówno w Szwecji, jak i w innych państwach. W latach 2000 i 2012 można było odnotować mniej korzystną sytuację mężczyzn niż kobiet na rynku pracy (2000 - M: 5,9\%, K: 5,3\%; 2012 - M: 8,2\%, K: 7,7\%).

5 U. Lundberg, K. Åmark, Rozwój państwa socjalnego w Szwecji w XX wieku, w: Państwo socjalne w Europie. Historia - Rozwój - Perspektywy, red. K. Kraus, T. Geisen, K. Piątek, Toruń 2005, s. 241-242, 249-250, 261-262. 
Tabela 1. Wskaźnik zatrudnienia i stopa bezrobocia według płci w państwach członkowskich Unii Europejskiej w latach 2000-2012

\begin{tabular}{|c|c|c|c|c|c|c|c|c|c|c|c|c|c|c|c|c|c|c|}
\hline & \multicolumn{6}{|c|}{2000} & \multicolumn{6}{|c|}{2006} & \multicolumn{6}{|c|}{2012} \\
\hline & \multicolumn{3}{|c|}{ Wskaźnik zatrudnienia } & \multicolumn{3}{|c|}{ Stopa bezrobocia } & \multicolumn{3}{|c|}{ Wskaźnik zatrudnienia } & \multicolumn{3}{|c|}{ Stopa bezrobocia } & \multicolumn{3}{|c|}{ Wskaźnik zatrudnienia } & \multicolumn{3}{|c|}{ Stopa bezrobocia } \\
\hline & \begin{tabular}{|l|} 
ogółem \\
\end{tabular} & $\mathrm{M}$ & $\mathrm{K}$ & ogółem & $\mathrm{M}$ & $\mathrm{K}$ & ogółem & $\mathrm{M}$ & $\mathrm{K}$ & ogółem & $\mathrm{M}$ & $\mathrm{K}$ & ogółem & $\mathrm{M}$ & $\mathrm{K}$ & ogółem & $\mathrm{M}$ & $\mathrm{K}$ \\
\hline UE-27 & 66,6 & 76,0 & 57,3 & 8,8 & 7,8 & 10,1 & 69,0 & 76,9 & 61,1 & 8,3 & 7,6 & 9 & 68,5 & 74,6 & 62,4 & 10,5 & 10,4 & 10,5 \\
\hline Austria & 71,4 & 80,6 & 62,3 & 3,6 & 3,1 & 4,3 & 73,2 & 80,0 & 66,4 & 4,8 & 4,3 & 5,2 & 75,6 & 80,9 & 70,3 & 4,3 & 4,4 & 4,3 \\
\hline Belgia & 65,8 & 75,5 & 56,0 & 6,9 & 5,6 & 8,5 & 66,5 & 74,0 & 58,8 & 8,3 & 7,4 & 9,3 & 67,2 & 72,7 & 61,7 & 7,6 & 7,7 & 7,4 \\
\hline Bułgaria & 55,3 & 60,2 & 50,7 & 16,4 & 16,7 & 16,2 & 65,1 & 69,9 & 60,4 & 9,0 & 8,6 & 9,4 & 63,0 & 65,8 & 60,2 & 12,3 & 13,5 & 10,8 \\
\hline Cypr & 72,3 & 86,4 & 59,0 & 4,8 & 3,1 & 7,1 & 75,8 & 86,2 & 65,9 & 4,6 & 3,9 & 5,4 & 70,2 & 76,1 & 64,8 & 11,9 & 12,6 & 11,1 \\
\hline Czechy & 71,0 & 80,2 & 61,9 & 8,8 & 7,3 & 10,6 & 71,2 & 80,4 & 61,8 & 7,1 & 5,8 & 8,8 & 71,5 & 80,2 & 62,5 & 7,0 & 6,0 & 8,2 \\
\hline Dania & 78,0 & 82,9 & 72,9 & 4,3 & 3,9 & 4,8 & 79,4 & 83,8 & 74,8 & 3,9 & 3,3 & 4,5 & 75,4 & 78,6 & 72,2 & 7,5 & 7,5 & 7,6 \\
\hline Estonia & 67,4 & 72,4 & 62,9 & 13,6 & 14,5 & 12,6 & 75,8 & 79,5 & 72,5 & 5,9 & 6,1 & 5,6 & 72,1 & 75,2 & 69,3 & 10,2 & 11,0 & 9,3 \\
\hline Finlandia & 71,6 & 74,9 & 68,2 & 9,8 & 9,1 & 10,6 & 73,9 & 76,3 & 71,5 & 7,7 & 7,4 & 8,1 & 74,0 & 75,5 & 72,5 & 7,7 & 8,3 & 7,1 \\
\hline Francja & 67,8 & 75,6 & 60,3 & 9,0 & 7,5 & 10,8 & 69,3 & 74,9 & 63,8 & 9,2 & 8,5 & 10,1 & 69,3 & 73,8 & 65,0 & 10,2 & 10,1 & 10,4 \\
\hline Grecja & 61,9 & 78,8 & 45,5 & 11,2 & 7,4 & 17,1 & 65,7 & 80,3 & 51,2 & 8,9 & 5,6 & 13,6 & 55,3 & 65,3 & 45,2 & 24,3 & 21,4 & 28,1 \\
\hline Hiszpania & 60,7 & 76,9 & 44,5 & 11,7 & 8,2 & 17,0 & 68,7 & 80,7 & 56,4 & 8,5 & 6,3 & 11,6 & 59,3 & 64,5 & 54,0 & 25,0 & 24,7 & 25,4 \\
\hline Holandia & 74,3 & 84,3 & 64,1 & 3,1 & 2,4 & 3,9 & 76,3 & 83,5 & 69,0 & 4,4 & 3,9 & 5,0 & 77,2 & 82,5 & 71,9 & 5,3 & 5,3 & 5,2 \\
\hline Irlandia & 70,4 & 82,8 & 57,9 & 4,2 & 4,3 & 4,1 & 73,4 & 83,4 & 63,3 & 4,5 & 4,7 & 4,3 & 63,7 & 68,1 & 59,4 & 14,7 & 17,7 & 11,0 \\
\hline Litwa & 65,6 & 67,4 & 63,9 & 16,4 & 18,8 & 14,0 & 71,6 & 75,2 & 68,3 & 5,8 & 6,0 & 5,6 & 68,5 & 69,1 & 67,9 & 13,4 & 15,2 & 11,6 \\
\hline Luksemburg & 67,4 & 80,7 & 53,8 & 2,2 & 1,8 & 2,9 & 69,1 & 78,9 & 59,4 & 4,6 & 3,5 & 5,9 & 71,4 & 78,5 & 64,1 & 5,1 & 4,5 & 5,8 \\
\hline Łotwa & 63,5 & 68,2 & 59,3 & 14,3 & 15,3 & 13,3 & 73,5 & 78,2 & 69,1 & 7,0 & 7,3 & 6,7 & 68,1 & 70,0 & 66,4 & 15,0 & 16,2 & 14,0 \\
\hline Malta & 57,2 & 80,9 & 33,2 & 6,7 & 6,4 & 7,4 & 57,6 & 79,3 & 35,3 & 6,9 & 6,1 & 8,6 & 63,1 & 79,0 & 46,8 & 6,4 & 5,9 & 7,3 \\
\hline Niemcy & 68,8 & 76,5 & 60,9 & 8,0 & 7,7 & 8,4 & 71,1 & 77,2 & 65,0 & 10,3 & 10,3 & 10,2 & 76,7 & 81,8 & 71,5 & 5,5 & 5,7 & 5,2 \\
\hline Polska & 61,0 & 68,0 & 54,2 & 16,1 & 14,4 & 18,2 & 60,1 & 67,3 & 53,1 & 13,9 & 13,0 & 15,1 & 64,7 & 72,0 & 57,5 & 10,1 & 9,4 & 10,9 \\
\hline Portugalia & 73,5 & 82,3 & 65,1 & 4,5 & 3,8 & 5,2 & 72,7 & 79,2 & 66,3 & 8,6 & 7,9 & 9,3 & 66,5 & 69,9 & 63,1 & 15,9 & 16,0 & 15,8 \\
\hline Rumunia & 69,1 & 75,4 & 63,0 & 6,8 & 7,2 & 6,3 & 64,8 & 71,2 & 58,5 & 7,3 & 8,2 & 6,1 & 63,8 & 71,4 & 56,3 & 7,0 & 7,6 & 6,4 \\
\hline Słowacja & 63,5 & 70,0 & 57,2 & 18,9 & 19,0 & 18,7 & 66,0 & 74,6 & 57,5 & 13,5 & 12,4 & 14,8 & 65,1 & 72,8 & 57,3 & 14,0 & 13,5 & 14,5 \\
\hline Słowenia & 68,5 & 73,2 & 63,6 & 6,7 & 6,5 & 7,0 & 71,5 & 76,3 & 66,5 & 6,0 & 4,9 & 7,2 & 68,3 & 71,8 & 64,6 & 8,9 & 8,4 & 9,4 \\
\hline Szwecja & 77,7 & 80,1 & 75,3 & 5,6 & 5,9 & 5,3 & 78,8 & 81,7 & 75,8 & 7,1 & 6,9 & 7,2 & 79,4 & 81,9 & 76,8 & 8,0 & 8,2 & 7,7 \\
\hline Węgry & 61,2 & 68,9 & 53,9 & 6,3 & 6,8 & 5,6 & 62,6 & 69,9 & 55,7 & 7,5 & 7,2 & 7,8 & 62,1 & 68,1 & 56,4 & 10,9 & 11,2 & 10,6 \\
\hline W. Brytania & 74,0 & 81,4 & 66,8 & 5,4 & 5,9 & 4,8 & 75,2 & 82,0 & 68,6 & 5,4 & 5,8 & 4,9 & 74,2 & 80,0 & 68,4 & 7,9 & 8,3 & 7,4 \\
\hline Włochy & 57,4 & 72,8 & 42,2 & 10,0 & 7,7 & 13,6 & 62,5 & 75,5 & 49,6 & 6,8 & 5,4 & 8,8 & 61,0 & 71,6 & 50,5 & 10,7 & 9,9 & 11,9 \\
\hline
\end{tabular}

${ }^{\mathrm{a}}$ Wszystkie dane prezentowane dla Unii Europejskiej wskazano dla 27 państw, w tym Rumunii i Bułgarii, które członkami stały się w 2007 r.

Źródło: Opracowanie własne na podstawie danych Eurostatu: Employment rate, unemployment rate, http://epp.eurostat.ec.europa.eu/portal/page/portal/employment_unemployment_lfs/data/database, dostęp 8.03.2014. 
Rosnący udział kobiet szwedzkich w rynku pracy to zmiany sięgające lat 70. ubiegłego wieku. W okresie do 2000 r. rosło zatrudnienie kobiet (z 55,6\% do 75,3\%), co w konsekwencji spowodowało zmniejszenie liczby tych Szwedek, które zajmowały się wyłącznie prowadzeniem domu (z 36,7\% do 5,8\%). Dane porównawcze dla kobiet z małymi dziećmi wskazują na podobne tendencje, a co najistotniejsze - z upływem czasu różnice $\mathrm{w}$ ich sytuacji i sytuacji kobiet bez dzieci na rynku pracy uległy niemal całkowitemu zatarciu, choć startowały w 1968 r. z zupełnie innych poziomów - zatrudnienie kobiet z dziećmi było ponad 20 pkt. proc. niższe ${ }^{6}$. Sytuacja ta pozostaje bez większych zmian, jeśli wziąć pod uwagę najnowsze dane w tym zakresie za 2011 r. Wskazują one na brak istotnego wpływu posiadania dzieci na status na rynku pracy ${ }^{7}$. Potwierdzają to również dane co do liczby osób pracujących w podziale na różne grupy wiekowe. W Szwecji różnica w liczbie zatrudnionych kobiet i mężczyzn w przedziale wiekowym 25-44 lata, w którym w państwach takich jak np. Polska w związku z urodzeniem i wychowaniem dzieci poziom zatrudnienia dla kobiet jest znacznie niższy niż w przypadku mężczyzn ${ }^{8}$, nie jest znacząca (według porównywalnych danych dla Polski i Szwecji w 2011 r.) $)^{9}$.

Najwyższym wskaźnikom zatrudnienia Szwedek towarzyszy podobna tendencja w odniesieniu do kobiet w wieku 55-64 lata (rysunek 1). Szwecja w 2012 r. osiągnęła najwyższy poziom zatrudnienia w tej grupie wiekowej - 69,6\%. Różnica w stosunku do zatrudnienia mężczyzn była ponad dwukrotnie mniejsza niż dla średniej unijnej (UE-27: 14,6 pkt. proc.) i jedynie w czterech państwach członkowskich była ona mniejsza niż w Szwecji (na niekorzyść kobiet: Łotwa - 0,7 pkt. proc., Finlandia - 3,1, Francja - 5,7, Szwecja - 6,7 i Estonia - 1,4 na niekorzyść mężczyzn). Dezaktywację osób powyżej 55 roku życia na rynku pracy determinują głównie uwarunkowania instytucjonalne dotyczące wieku przejścia na emeryturę czy możliwości uzyskania prawa do świadczeń przedemerytalnych. Te czynniki wpływają również na różnice pomiędzy płciami. Mniejsze znaczenie, niemniej istotne w przypadku kobiet, ma opieka nad osobami starszymi. W Polsce, którą cechuje ponad 20 pkt. proc. różnicy

6 T. Korpi, Ch. Stern, Globalization, deindustralization and the labor market experiences of Swedish women, 1950 to 2000, w: Globalization, uncertainty and women's careers: an international comparison, red. H.-P. Blossfeld, H. Hofmeister, Edward Elgar, Cheltenham 2006, s. 125-126.

7 Women and man in Sweden. Facts and Figures 2012, Statistics Sweden 2012, s. 51-55.

8 Aktywność ekonomiczna ludności w wieku 15 lat i więcej wedtug wieku na podstawie spisu w 2011 roku, Rocznik Statystyczny Rzeczypospolitej Polskiej 2013, s. 232, http://www.stat.gov.pl/cps/rde/xbcr/gus/RS_ rocznik_statystyczny_rp_2013.pdf, dostęp 29.03.2014.

9 Population aged 15-74 (LFS), thousands by sex, age, labour status and year, Statistics Sweden, http:// www.scb.se/en_/Finding-statistics/Statistical-Database/TabellPresentation/?layout=tableViewLayout1 \&rxid=c04f6911-f554-4143-a5d1-3801d215a5e $\mathrm{e}^{2}$, dostęp 8.03.2014. 
w zatrudnieniu kobiet i mężczyzn po 55 roku życia, pozostaje ona domeną kobiet ${ }^{10}$. W Szwecji wydaje się natomiast nie mieć wpływu na różnice pomiędzy płciami, co potwierdzają również dane statystyczne w tym zakresie. W latach 2009-2010 pomoc starszym członkom rodziny w wieku 65-74 lata była udzielana w minimalnym stopniu zarówno przez władze miejskie, jak i przez osoby spokrewnione. Potrzeba pomocy w tym państwie wzrasta po ukończeniu 75 roku życia, w szczególności dla osób samotnych - $\mathrm{w}$ analizowanym okresie była ona udzielana w podobnym wymiarze przez rodzinę i władze. O niskim wpływie obowiązków związanych z opieką nad osobami starszymi na zatrudnienie kobiet w Szwecji świadczy również niewielka liczba osób, w porównaniu z podobnymi obowiązkami w stosunku do dzieci, dla których te zadania stanowią przyczynę podjęcia pracy w niepełnym wymiarze czasu pracy. I chociaż opieka w jednym i drugim przypadku pozostaje domeną kobiet (93\% i 90\% udziału odpowiednio), w przypadku osób spokrewnionych jedynie 4 tys. osób (w porównaniu ze 144 tys. w związku z opieką nad dzieckiem) pracowało w niepełnym wymiarze czasu pracy spowodowanym obowiązkami opiekuńczymi ${ }^{11}$.

Rysunek 1. Wskaźnik zatrudnienia osób w wieku 55-64 lata według płci w państwach członkowskich Unii Europejskiej w 2012 r. (w \%)

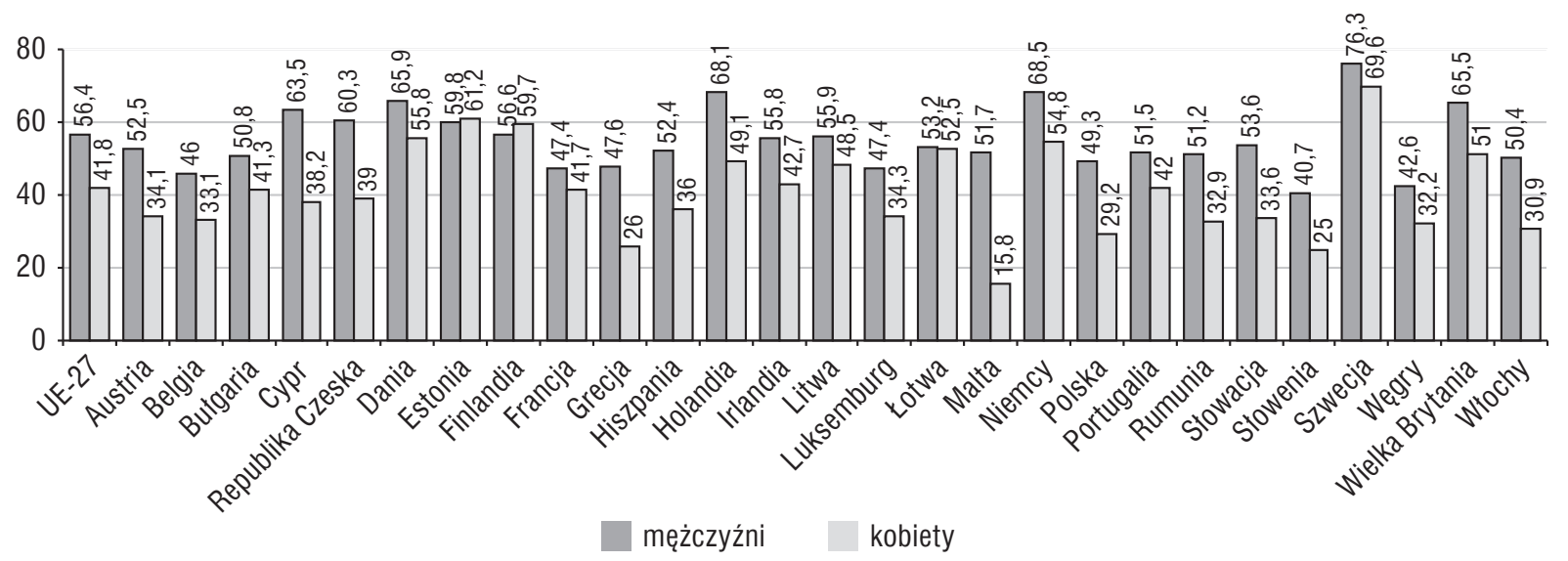

Źródło: Opracowanie własne na podstawie danych Eurostatu: Employment rate of older workers, http://epp. eurostat.ec.europa.eu/tgm/table.do?tab=table\&init $=1 \&$ plugin $=1 \&$ language $=$ en\&pcode $=$ tsdde100, dostęp 24.02.2014.

10 Zob. szerzej: Diagnoza społeczna 2011. Warunki i jakość życia Polaków, red. J. Czapiński, T. Panek, „Contemporary Economics" September 2011, Vol. 5, Issue 3, http://ce.vizja.pl/en/issues/volume/5/issue/3\#art214, dostęp 28.01.2014.

11 Women and man in Sweden..., op.cit., s. 47, 49. 


\section{Uwarunkowania aktywności zawodowej kobiet na rynku pracy}

Analiza czynników wpływających na zapewnienie równych szans kobiet i mężczyzn na rynku pracy wykazuje dużą zbieżność poglądów i wyników prowadzonych badań, różnice odnoszą się jedynie do ważności poszczególnych elementów. Można wyróżnić trzy zasadnicze grupy uwarunkowań, które wzajemnie się przenikają i wpływają na kształt poszczególnych rozwiązań:

1) strategiczne - wskazujące na istnienie i prowadzenie konsekwentnej i spójnej polityki w zakresie równych szans kobiet i mężczyzn oraz godzenia życia zawodowego z prywatnym;

2) kulturowe - w sferze postaw i preferencji kształtujących zachowanie jednostek w rodzinie i na rynku pracy;

3) instytucjonalne - w tym zasadnicze rozwiązania w zakresie opieki nad osobami niesamodzielnymi, które mogą przybrać różną formę:

a) ułatwień związanych z czasem (urlop rodzicielski, przerwy w karierze zawodowej, zmniejszenie wymiaru czasu pracy itd.),

b) świadczeń pieniężnych (świadczenia rodzinne, pomoc społeczna, ulgi podatkowe, dofinansowanie usług domowych itd.),

c) usług rzeczowych (opieka domowa nad osobami starszymi, żłobki itd.) ${ }^{12}$.

\subsection{Istnienie strategicznych ram polityki w zakresie równych szans kobiet i mężczyzn na rynku pracy}

Polityka krajowa odgrywa kluczową rolę w zakresie zapewniania równości szans w obszarze zatrudnienia kobiet i mężczyzn. Państwa, które w swojej polityce społecznej wspierają konsekwentnie godzenie życia zawodowego z prywatnym i promują pełny i równy udział obu płci w rynku pracy, odnoszą sukces w zapewnieniu tego ostatniego. Cechują się także większą równością w podziale pomiędzy płatną pracą a tą w gospodarstwie domowym niż państwa $\mathrm{z}$ bardziej tradycyjnym podziałem ról czy nieposiadające polityki w zakresie równowagi na linii praca - rodzina ${ }^{13}$.

12 F. Bettio, J. Plantenga, Care regimes and the European employment rate, w: Institutions for social wellbeing: alternatives for Europe, red. L. Costabile, Palgrave Macmillan, Basingstoke, New York 2008, s. 153.

${ }^{13}$ L. den Dulk, A. van Doorne-Huiskes, op.cit., s. 48, 51-52; R. Gambles, S. Lewis, R. Rapoport, Evolutions and approaches to equitable divisions of paid work and care in three European countries: a multi-level change, w: Women, men, work..., op.cit., s. 17. 
Szwecja od lat prowadzi konsekwentną, spójną i całościową politykę w zakresie równości szans kobiet i mężczyzn, będąc prekursorem wielu rozwiązań na poziomie Unii Europejskiej ${ }^{14}$. Jej cechą charakterystyczną jest horyzontalne podejście do tych kwestii i ich uwzględnianie we wszystkich dziedzinach polityki. Co istotne, w celu zwiększenia aktywności zawodowej kobiet Sztokholm łączy politykę rodzinną, rynku pracy i w zakresie równości, zwiększając tym samym skuteczność prowadzonych działann ${ }^{15}$. W 2009 r. przyjęto rządową Strategię na rzecz równości szans płci na rynku pracy, która wskazuje jako priorytetowe oddziaływanie w sferze segregacji na rynku pracy i zapewnienia równych szans w przedsiębiorczości, równego udziału w życiu zawodowym oraz równych warunków pracy ${ }^{16}$.

Oprócz kierunków strategicznych Szwecja posiada również solidne podstawy prawne w zakresie działań antydyskryminacyjnych w zatrudnieniu ${ }^{17}$.

\subsection{Uwarunkowania kulturowe kształtujące postawy i wzorce zachowań}

Strategiczne podejście z jednej strony wynika z czynników kulturowych, które pozwalają na wyznaczenie kierunkó $w^{18}$, $\mathrm{z}$ drugiej strony bez zmian $\mathrm{w}$ sferze indywidualnych postaw i kultury nie można mówić o szansie na praktyczną realizację przyjętej polityki krajowej. W świetle badań bowiem przyjęta koncepcja polityczna w środowisku pracy, bez wsparcia innych czynników, nie przynosi zmian w strukturach, kulturze czy przyjętych praktykach ${ }^{19}$.

I to właśnie w przyjętych wzorcach kulturowych upatruje się głównych przyczyn długotrwałości procesu kształtowania równościowej polityki zatrudnieniowej

14 Zob. szerzej: J. Kantola, Polityka równości płci w Unii Europejskiej, Warszawa 2012; E. Lisowska, Równouprawnienie kobiet i mężczyzn w społeczeństwie, Warszawa 2010; G. Firlit-Fesnak, Wspólnotowa polityka na rzecz równości kobiet i mężczyzn. Ewolucja celów i instrumentów działania, Warszawa 2005.

${ }^{15}$ I. Jönsson, Reconciliation of work and family life: policies and practices in Western Europe, w: The future of work in Europe, red. P. Littlewood, I. Glorieux, I. Jönsson, Ashgate, Aldershot 2004, s. 6-148.

16 Szerzej zob. Strategy for gender equality in the labour market, http://www.government.se/sb/d/4096/a/ 130290, dostęp 8.03.2014.

17 Szerzej zob. M. Grzybowski, G. Kuca, Prawa kobiet w Szwecji, w: Prawa kobiet we współczesnym świecie, red. L. Kondratiewa-Bryzik, Warszawa 2011; A. Adlercreutz, B. Nyström, Labour law in Sweden, Wolters Kluwer Law and Business, Alphen aan den Rijn 2010.

18 U. Klammer, Na drodze od "modelu żywiciela” do "modelu osoby zarobkującej” o społecznym i socjalno-politycznym obcowaniu z praca opiekuńcza w Europie, w: Państwo socjalne w Europie. Historia - Rozwój - Perspektywy, op.cit., s. 382.

19 R. Gambles, S. Lewis, R. Rapoport, op.cit., s. 17. 
w Unii Europejskiej. Są one często elementem, który wymyka się z jasnego podziału charakterystycznego dla nowoczesnego czy bardziej tradycyjnego modelu państwa ${ }^{20}$.

Badania oparte na trzech wskaźnikach dotyczących postaw względem pracy zarobkowej, podziału pracy w gospodarstwie domowym i zatrudnienia matek, przeprowadzone z wykorzystaniem wyników International Social Survey Programme’s Family and Gender Relations Module z 2002 r. i pogłębione dla siedmiu państw (Czech, Francji, Hiszpanii, zachodnich Niemiec, Portugalii, Szwecji i Wielkiej Brytanii), pozwoliły na pokazanie cech, które mogą w sposób istotny kształtować wysoką aktywność zawodową Szwedek w porównaniu z innymi państwami. Szwedzkie wzorce co do łączenia pracy z życiem prywatnym cechują się największym udziałem zwolenników liberalnych postaw dotyczących udziału kobiet zarówno w pracy zarobkowej, jak i nieodpłatnej. Oznacza to, że oczekuje się równego podziału zadań i możliwości w tych dwóch aspektach. Jednocześnie w sposób tradycyjny podchodzi się do zatrudnienia matek, wspierając je w tym, by nie pracowały w pełnym wymiarze czasu pracy $z$ uwagi na niekorzystny wpływ braku obecności matki na wychowanie małych dzieci. Na tle badanych państw Szwecja cechuje się, wyraźnie odstającym od innych, najniższym poparciem dla silnie tradycyjnego modelu z ojcem zarabiającym i pozostającą w domu matką, oznaczającego konserwatywne podejście zarówno do pracy zarobkowej, nieodpłatnej w domu, jak i macierzyństwa. W Szwecji zauważalne jest znaczne odejście (w porównaniu z innymi państwami) od modelu męskiego żywiciela rodziny ${ }^{21}$, przy dużym wsparciu równowagi w życiu zawodowym i rodzinnym nieosiąganym poprzez pozostanie matek $\mathrm{w}$ domu czy ich pracę $\mathrm{w}$ pełnym wymiarze czasu pracy (jak np. we Francji, Portugalii czy Hiszpanii, gdzie praca w niepełnym wymiarze czasu nie stanowi powszechnego rozwiązania), ale na niepełny etat przy zachowaniu podwójnego modelu opieki. Oprócz 1/3 respondentów w Szwecji, którzy tradycyjnie podchodzą do relacji na linii praca - dom (20\% zwolenników tradycyjnego męskiego modelu żywiciela rodziny i $10 \%$ sprzyjających podwójnemu modelowi o nierównym podziale ról w pracy nieodpłatnej), pozostała część opowiada się za modelem podwójnego żywiciela rodziny, w którym praca w niepełnym wymiarze czasu kobiet wychowujących małe dzieci stanowi kluczowy element w zachowaniu równowagi w życiu prywatnym i zawodowym ${ }^{22}$. Co więcej, w badaniach prowadzonych w latach 90. i powtórzonych w 2000 r. w Szwecji najsłabiej zgadzano się

${ }^{20} \mathrm{~K}$. Wall, Main patterns in attitudes to the articulation between work and family life: a cross-national analysis, w: Women, men, work..., op.cit., s. 86-88.

21 Podobne konkluzje wynikają z badań przeprowadzonych przez Jane Lewis w czterech państwach (Francji, Irlandii, Szwecji, Wielkiej Brytanii). Zob. szerzej: P. Michoń, Płeć w modelach polityki społecznej, „Problemy Polityki Społecznej. Studia i Dyskusje” 2004, nr 7, s. 83.

22 K. Wall, op.cit., s. 97-98, 107. 
z opinią o konieczności pozostania matki w domu do momentu, kiedy dziecko nie rozpocznie szkoły. Z tym stwierdzeniem zgadzało się jedynie 29\% Szwedów wobec np. 76\% Polaków ${ }^{23}$.

W opiece nad osobami starszymi kluczowe znaczenie mają takie wartości funkcjonujące w szwedzkim społeczeństwie, jak luźne więzi rodzinne, niewielkie oczekiwanie wsparcia ze strony członków rodziny ukierunkowane na pomoc państwa, a także duże poczucie samodzielności i potrzeby aktywności. Wszystko to powoduje, że z jednej strony nie oczekuje się wsparcia rodziny, z drugiej fakt bycia aktywnym sprzyja pozostawaniu dłużej w dobrym zdrowiu i budowaniu relacji w społecznościach lokalnych ${ }^{24}$. W Szwecji istnieje też duże poparcie dzieci dla zorganizowanej opieki dla rodziców. W sondażu Eurobarometru z 2002 r. wśród 28 ankietowanych państw Szwecja miała najniższy poziom poparcia dla ewentualnego zwiększenia obowiązków po stronie rodziny w związku z opieką nad osobami starszymi - jedynie około $30 \%$ badanych popierało takie rozwiązanie, podczas gdy w państwie lidera (Grecji) zwolennicy stanowili blisko 90\%. W Polsce udział ten był niewiele niższy - 80\% ${ }^{25}$. Należy przy tym podkreślić, że postawy te nie oznaczają braku jakiegokolwiek zaangażowania młodszych pokoleń w pomoc osobom starszym - jedynie w porównaniu $\mathrm{z}$ innymi państwami wsparcie to jest mniej intensywne i regularne. Jednocześnie i w tym przypadku kultura przenika się z prowadzoną polityką publiczną. $\mathrm{Na}$ początku XX w. wsparcie rodzin było dużo szersze ${ }^{26}$, niemniej wraz z urbanizacją nastąpiła zmiana struktury demograficznej poszczególnych rejonów Szwecji, co wpłynęło na rozluźnienie więzi i konieczność większego wsparcia po stronie państwa. Dyskusyjne może też być, na ile wprowadzenie w 1979 r. ustawy, która zmniejszała obowiązki dzieci wobec rodziców, było efektem zaangażowania państwa w opiekę, a na ile odzwierciedlało postawy i preferencje Szwedów.

${ }^{23}$ M. Kocik, Europejskie modele polityki rodzinnej wobec wyzwań demograficznych, „Problemy Polityki Społecznej. Studia i Dyskusje” 2006, nr 9, s. 104.

${ }^{24}$ R. Bakalarczyk, Opieka nad seniorami w państwie opiekuńczym - przykład Szwecji, „Problemy Polityki Społecznej. Studia i Dyskusje" 2012, nr 18, s. 112.

${ }^{25} \mathrm{~J}$. Alber, U. Köhler, Quality of life in Europe. Health and care in an enlarged Europe, European Foundation for the Improvement of Living and Working Conditions, Luxembourg 2004, s. 65, http://www.eurofound.europa.eu/publications/htmlfiles/ef03107.htm, dostęp 1.04.2011.

${ }^{26}$ Od 1954 do 2000 r. opieka po stronie rodziny zmniejszyła się z 77\% do 37\%, na korzyść wsparcia instytucjonalnego. Zob. L. Johansson, G. Sundstrom, Policies and practices in support of family caregivers - filial obligations redefined in Sweden, „Journal of Ageing \& Social Policy” 2006, No. 3/4, s. 12. 


\subsection{Rozwiązania instytucjonalne}

\subsubsection{Proces kształtowania instrumentów w zakresie wsparcia kobiet na rynku pracy na przestrzeni XX i XXI w.}

Szwedzki system charakteryzuje szeroki zakres rozwiązań instytucjonalnych i struktur wspierających zatrudnienie kobiet i godzenie życia zawodowego z prywatnym, dostosowujących się do zmieniających się realiów na rynku pracy. Działania w tym zakresie podejmowane są od lat.

W obszarze polityki rodzinnej kluczowe znaczenie ma system urlopów związanych z urodzeniem i wychowaniem dziecka oraz formy instytucji opieki nad dzieckiem. Urlop macierzyński wprowadzono w 1901 r. na okres 4 tygodni - wówczas nie towarzyszyły mu dodatkowe świadczenia. Zmieniło się to w $1938 \mathrm{r}$. wraz z upoważnieniem kobiet do korzystania z 6-miesięcznego zasiłku. W 1974 r. Szwecja, jako pierwsze państwo, rozszerzyła świadczenia w tym zakresie również na mężczyzn, wprowadzając urlop rodzicielski. W kolejnych latach zwiększano jego wymiar czasowy i finansowy. Jednocześnie od lat 80 . XX w. szeroko promowano wykorzystanie urlopu przez ojców, m.in. wprowadzając w 1995 r. tzw. ojcowski miesiąc, z którego rezygnacja wiązała się z utratą prawa do świadczeń, a w 2002 r. wydłużono ten okres do 2 miesięcy ${ }^{27}$.

Po II wojnie światowej w szwedzkiej polityce zasada równych szans kobiet i mężczyzn znajdowała coraz większe odzwierciedlenie. Publiczne instytucje opieki nad dziećmi powstały już w latach 60 . XX w., przy czym w tamtym okresie funkcjonowały głównie w dużych ośrodkach miejskich. Od tego czasu system ten znacznie się rozwinął, co wynikało głównie z ubytków na rynku pracy i konieczności zaktywizowania tych zasobów, które dotąd pozostawały nieaktywne, co w dużej mierze dotyczyło kobiet ${ }^{28}$. W tamtym też okresie na fali krytyki dotychczasowych nieformalnych form opieki nad dzieckiem, jako niekorzystnych dla jego rozwoju, podjęto decyzję o konieczności przejęcia przez państwo odpowiedzialności za te działania, co stanowi podstawowe założenie do czasów współczesnych ${ }^{29}$. Jednocześnie od lat 70. ubiegłego wieku zapewnienie publicznych form opieki nad dziećmi w połączeniu z urlopami rodzicielskimi stanowi podstawę szwedzkiej polityki w zakresie wsparcia zatrudnienia kobiet ${ }^{30}$. W latach 90 . XX w. podniesiono standardy opiekuńczości

27 Zob. szerzej: T. Korpi, Ch. Stern, op.cit., s. 123; Women and man in Sweden..., op.cit., s. 7-11, 44-46; J. Wiśniewski, op.cit., s. 104-105.

28 T. Korpi, Ch. Stern, op.cit., s. 123.

29 Szerzej zob. B. Balcerzak-Paradowska, Polityka rodzinna między dwoma modelami, „Opracowanie PBZ" 1999, nr 10, s. 20-21.

30 Szerzej zob. I. Jönsson, op.cit., s. 148. 
państwa i jednocześnie zmniejszono udział środków publicznych przeznaczonych na funkcje opiekuńcze. W tym okresie opieka nad dzieckiem nabrała cech powszechności. W 1995 r. samorządy zostały zobowiązane do zapewnienia opieki wszystkim dzieciom poniżej 12 roku życia pracujących i studiujących matek. Pięć lat później zapewniono dodatkowe wsparcie dla matek na urlopie rodzicielskim i bezrobotnych - od tej pory ich dzieci miały zostać również objęte opieką przedszkolną ${ }^{31}$.

Nie bez znaczenia w zakresie zwiększenia aktywności zawodowej kobiet były również rozwiązania $\mathrm{w}$ sferze prawa podatkowego, świadczeń rodzinnych czy emerytur. W 1948 r. wprowadzono w Szwecji powszechne zasiłki rodzinne. Od 1971 r. (z okresem przejściowym do lat 80. XX w.) w Szwecji obowiązuje oddzielne opodatkowanie ${ }^{32}$, które spowodowało większą opłacalność pracy dwojga rodziców. Natomiast w 1999 r., zrównując wiek emerytalny kobiet i mężczyzn, w systemie naliczania składek emerytalnych przewidziano mechanizmy, które uwzględniały potrzeby kobiet i czas poświęcony na opiekę nad dzieckiem.

$\mathrm{W}$ polityce wsparcia osób starszych do lat 50 . XX w. koncentrowano się na zapewnieniu zewnętrznej pomocy w domach opieki. Po tym okresie priorytetem, aktualnym do dzisiaj ${ }^{33}$, stały się usługi udzielane w domach osób starszych. Wraz ze zwiększeniem liczby osób wymagających opieki od lat 90 . XX w. coraz częściej rolę usługodawców zaczynają pełnić podmioty prywatne ${ }^{34}$. Na budowie systemu wsparcia instytucjonalnego Szwecja koncentrowała się w pierwszej kolejności i do dziś stanowi on kluczowy filar tej polityki. Jednocześnie w tym samym okresie zaczęto odkrywać potencjał rodzin w zakresie zapewnienia nieformalnej opieki i w konsekwencji od 2009 r. wspierać nieformalnych opiekunów, przy czym działania na tym polu nie mają zastąpić obowiązków państwa, a jedynie wspierać przy jego silnym udziale. Takie podejście jest również zgodne z priorytetem Sztokholmu, jakim jest zapewnienie usług opiekuńczych jak najbliżej środowiska, w którym żyją starsze osoby ${ }^{35}$.

${ }^{31}$ Szerzej zob. J. Wiśniewski, op.cit., s. 103-104; A.-Z. Duvander, T. Lappegard, G. Andersson, Family policy and fertility: fathers' and mothers' use of parental leave and continued childbearing in Norway and Sweden, „Journal of European Social Policy” 2010, No. 1, s. 46-47.

32 Zob. szerzej: D. Anxo, D. Storrie, Working-time transitions in Sweden, w: Regulating working-time transitions in Europe, red. J. O'Reilly, Edward Elgar, Cheltenham 2003, s. 71-73.

33 Ta tendencja utrzymywała się również w 2012 r., dodatkowo Szwecję cechuje wysoki przyrost udziału opieki domowej w stosunku do opieki w domach opieki - od 2000 r. do 2011 r. nastąpił wzrost z 55,5\% do 69,9\%. OECD Reviews of Health Care Quality: Sweden 2013, Raising standards, OECD 2013, s. 129, 131, http://www.oecd-ilibrary.org/social-issues-migration-health/oecd-reviews-of-health-care-quality-sweden-2013/long-term-care-in-sweden_9789264204799-7-en, dostęp 1.04.2014.

${ }^{34} \mathrm{~K}$. Zapędowska-Kling, Polityka społeczna wobec osób starszych w krajach skandynawskich - przykłady dobrych praktyk, „Acta Universitatis Lodziensis, Folia Oeconomica” 2013, nr 291, s. 35-36.

35 R. Bakalarczyk, Opieka nad seniorami..., op.cit., s. 115-116; R. Bakalarczyk, System opieki nad seniorami w Szwecji - lekcje dla Polski, „Analizy Norden Centrum” 2012, nr 6, s. 5-6. 
Kluczowym założeniem systemu kreowanego w Szwecji na przestrzeni kilku ostatnich dziesięcioleci, poprzez zakres tworzonych instrumentów, jest wspieranie modelu rodziny o wysokim poziomie aktywności zawodowej obojga rodziców, w którym dąży się do równego podziału obowiązków w rodzinie i poza nią.

\subsubsection{Aktualnie obowiązujące rozwiązania w zakresie opieki nad osobami zależnymi}

Szwecję charakteryzuje rozbudowany system form publicznej opieki nad osobami zależnymi połączony z hojnym systemem świadczeń urlopowych wynikających $\mathrm{z}$ urodzenia i posiadania dzieci. Jego szczegóły przedstawiono w tabeli 2. Rozwiązania szwedzkie w znacznym stopniu wyróżniają się na tle innych państw, czyniąc z tego państwa często lidera czy prekursora nowych rozwiązań.

\section{Tabela 2. Formy wsparcia opieki nad dziećmi i osobami starszymi finansowane ze środków publicznych}

\begin{tabular}{|c|c|c|}
\hline \multicolumn{3}{|c|}{ Wsparcie w związku z opieką nad dziećmi } \\
\hline ułatwienia związane z czasem & świadczenia pieniężne & usługi rzeczowe \\
\hline $\begin{array}{l}\text { 1) Urlop macierzyński - } 7 \text { tygodni przed i po dacie } \\
\text { porodu. } \\
\text { 2) Urlop ojcowski - } 10 \text { dni w związku z narodzinami } \\
\text { dziecka, z czasowymi świadczeniami do } \\
\text { wykorzystania w } 60 \text { dni od wyjścia dziecka ze } \\
\text { szpitala. } \\
\text { 3) Pełny urlop rodzicielski z zasitkiem opiekuńczym } \\
\text { lub bez do } 18 \text { miesiąca życia dziecka; zasitek } \\
\text { opiekuńczy płatny przez } 480 \text { dni do } 8 \text { roku życia } \\
\text { dziecka lub ukończenia pierwszej klasy szkoły } \\
\text { (w wysokości do } 80 \% \text { dochodu, z uwzględnieniem } \\
\text { górnej granicy kwotowej na stosunkowo wysokim } \\
\text { poziomie); dwumiesięczna nietransferowalna } \\
\text { kwota ojcowska. } \\
\text { 4) Częściowy urlop z zasiłkiem opiekuńczym } \\
\text { - zmniejszony wymiar czasu pracy o różny okres } \\
\text { połączony z cześciowymi świadczeniami. } \\
\text { 5) Cześciowy urlop bez zasitku opiekuńczego } \\
\text { - zmniejszony wymiar czasu pracy do 1/4 aż } \\
\text { dziecko ukończy } 8 \text { lat lub pierwszy rok szkoły. } \\
\text { 6) Urlop z czasowym zasitkiem opiekuńczym } \\
\text { w zwiazzku z opieką nad chorym dzieckiem. } \\
\text { 7) Instrument kompensacyjny za lata spędzone } \\
\text { z dzieckiem na poczet przyszłej emerytury } \\
\text { - przysługuje rodzicom przez pierwsze } 4 \text { lata } \\
\text { życia dziecka bez względu na korzystanie } \\
\text { z urlopów rodzicielskich. } \\
\text { 8) Bonus równościowya - świadczenie finansowe } \\
\text { wprowadzone w } 2008 \text { r., by zachęcić do } \\
\text { dzielenia się urlopem rodzicielskim pomiędzy } \\
\text { matką a ojcem w jak największym stopniu; do } \\
\text { uruchomienia zgodnie z uznaniem samorządów } \\
\text { po wykorzystaniu } 250 \text { dni urlopu rodzicielskiego. }\end{array}$ & $\begin{array}{l}\text { 1) Zasitki rodzinne } \\
\text { - w równej wysokości } \\
\text { na każde dziecko do } \\
16 \text { roku życia (i dłużej } \\
\text { pod warunkiem } \\
\text { kontynuowania } \\
\text { nauki w szkole } \\
\text { ponadpodstawowej); } \\
\text { specjalny zasitek dla } \\
\text { rodzin wielodzietnych. } \\
\text { 2) Zasitki zwiazzane } \\
\text { z wychowaniem } \\
\text { dziecka w wieku } \\
\text { od 1-3 lat - do } \\
\text { uruchomienia } \\
\text { zgodnie z uznaniem } \\
\text { samorzadów } \\
\text { po wykorzystaniu } \\
\text { 250 dni urlopu } \\
\text { rodzicielskiego. } \\
\text { 3) Zasitek mieszkaniowy. } \\
\text { 4) Ulgi podatkowe - brak } \\
\text { ulg na dzieci. }\end{array}$ & $\begin{array}{l}\text { 1) Placówki opieki dziennej - dzieci } \\
\text { 0-6 lat, czynne do godziny 18:00 } \\
\text { (najszerszy zakres). } \\
\text { 2) Opieka częściowa - dzieci } \\
\text { 5-6 lat pod jednoczesną } \\
\text { domową opieką sprawowaną } \\
\text { przez rodziców/opiekunów; ich } \\
\text { celem - przygotowanie do zajęć } \\
\text { szkolnych (3h dziennie). } \\
\text { 3) Samorzadowa opieka rodzinna } \\
\text { - prowadzona przez opiekunów } \\
\text { w ich domach; jakość pracy } \\
\text { nadzorowana przez samorządy. } \\
\text { 4) Otwarte przedszkola - placówki } \\
\text { oferujące zajęcia edukacyjne } \\
\text { i rekreacyjne, w których dzieci } \\
\text { znajdują się również pod opieką } \\
\text { rodziców; udział nie wymaga } \\
\text { rejestracji. } \\
\text { 5) Stowarzyszenia centrów } \\
\text { opiekuńczych - finansowane } \\
\text { przez samorządy, prowadzone } \\
\text { przez stowarzyszenia rodziców } \\
\text { wspótuczestniczących w różnych } \\
\text { dodatkowych zadaniach. } \\
\text { 6) Zajęcia pozalekcyjne - dzieci } \\
\text { 7-12 lat. } \\
\text { 7) Pomoc domowa prowadzona } \\
\text { przez pielęgniarki - dla chorych } \\
\text { i niepełnosprawnych dzieci oraz } \\
\text { chorych matek opiekujących się } \\
\text { dziećmi. }\end{array}$ \\
\hline
\end{tabular}




\begin{tabular}{|c|c|c|c|}
\hline \multicolumn{4}{|c|}{ Usługi w zakresie opieki nad osobami starszymi } \\
\hline \multicolumn{3}{|c|}{ wsparcie zinstytucjonalizowane } & \multirow[b]{2}{*}{ wsparcie przez rodzinę } \\
\hline $\begin{array}{c}\text { świadczenia } \\
\text { instytucjonalne (,specjalne } \\
\text { mieszkalnictwo") }\end{array}$ & świadczenia w domu & inne & \\
\hline $\begin{array}{l}\text { W formie pobytu } \\
\text { w placówkach } \\
\text { zapewniających opiekę } \\
\text { i realizację różnego rodzaju } \\
\text { usług na rzecz osób } \\
\text { starszych. W ramach tych } \\
\text { placówek funkcjonują różne } \\
\text { formy: domy opieki, ośrodki } \\
\text { opieki (domy spokojnej } \\
\text { starości, tzw. domy } \\
\text { usługowe, domy grupowe } \\
\text { dla osób z demencją) itd. }\end{array}$ & $\begin{array}{l}\text { 1) Usługi domowe (zakupy, } \\
\text { gotowanie, sprzątanie } \\
\text { itd.). } \\
\text { 2) Usługi pielęgnacyjne } \\
\text { (higiena osobista, pomoc } \\
\text { w ubieraniu, wstawaniu } \\
\text { z tóżka itd.). }\end{array}$ & $\begin{array}{l}\text { Usługi świadczone } \\
\text { w środowisku lokalnym } \\
\text { dotyczące różnego } \\
\text { rodzaju ułatwień } \\
\text { w funkcjonowaniu w domu } \\
\text { i poza nim i ośrodkami } \\
\text { opieki (transport, } \\
\text { wyżywienie, dostosowanie } \\
\text { mieszkania, wsparcie } \\
\text { niepełnosprawnych, } \\
\text { systemy alarmowe). }\end{array}$ & $\begin{array}{l}\text { 1) Wsparcie nieformalnych } \\
\text { opiekunów poprzez } \\
\text { podnoszenie kwalifikacji } \\
\text { i umiejętności, } \\
\text { tzw. opieke } \\
\text { wytchnieniową, zasitki } \\
\text { dla opiekuna i osoby } \\
\text { znajdującej się pod } \\
\text { opieką, płatny urlop } \\
\text { na opiekę. } \\
\text { 2) Inne formy organizowane } \\
\text { przez władze lokalne, } \\
\text { np. miejsca spotkań dla } \\
\text { opiekunów, centra/grupy } \\
\text { wsparcia. }\end{array}$ \\
\hline
\end{tabular}

${ }^{a}$ Szerzej na temat wpływu tego instrumentu na równy podział ról opiekuńczych zob. P. Tunberger, W. Sigle-Rushton, Continuity and change in Swedish family policy reforms, „Journal of European Social Policy” 2011, No. 3.

Źródło: Opracowanie własne na podstawie: A transnational report. Creating innovative working arrangements through the support of public employment services for a better work life reconciliation, red. M. Fsadni, September 2009, http://etc.gov.mt/Resources/file/Resources/2009\%20-\%20Creating\%20Innovative\%20Working\%20 Arrangements\%20Report_pdf.pdf, dostęp 28.03.2014, s. 78-79, 86-87; B. Balcerzak-Paradowska, Polityka rodzinna między dwoma modelami, „Opracowanie PBZ” 1999, nr 10, s. 17, 21-22; D. Szelewa, Szwedzka polityka rodzinna, „Problemy Polityki Społecznej. Studia i Dyskusje” 2004, nr 7, s. 65-71: R. Bakalarczyk, Opieka nad seniorami w państwie opiekuńczym - przykład Szwecji, „Problemy Polityki Społecznej. Studia i Dyskusje” 2012, nr 18, s. 114-116; R. Bakalarczyk, System opieki nad seniorami w Szwecji - lekcje dla Polski, „Analizy Norden Centrum” 2012, nr 6, s. 6; R. Bakalarczyk, Edukacja przedszkolna w Szwecji - lekcje dla Polski, „Analizy Norden Centrum" 2011, nr 4, s. 2, 6-7.

Instytucje opieki nad dzieckiem charakteryzuje szerokie spektrum przystępnych cenowo różnych możliwości wyboru w zależności od potrzeb i sytuacji rodzinno-zawodowej. Polityka państwa prowadzona od lat 70. ubiegłego wieku przyniosła wyraźne efekty. Od 1972 do 2011 r. udział dzieci w wieku 1-6 lat w różnych formach opieki nieustannie wzrastał, startując z niskiego poziomu 12\% w 1972 r. i osiągając poziom blisko 70\% w 2011 r. Zdecydowanie największa dynamika zmian miała miejsce do 1990 r., kiedy to nastąpił blisko pięciokrotny wzrost udziału dzieci w formalnej opiece gwarantowanej przez państwo (rysunek 2).

Polityka krajowa w zakresie zapewniania formalnej opieki nad dziećmi przynosi również wymierne efekty w porównaniu z wynikami na poziomie Unii Europejskiej (tabela 3). W 2011 r. Szwecję cechował, na tle innych państw członkowskich, jeden z najwyższych udziałów dzieci ( $w$ wieku od 0 do momentu rozpoczęcia obowiązkowego kształcenia) w różnych formach opieki. W każdym przypadku jej wyniki kształtują się korzystniej niż średnia dla całej UE. Jedynie 49\% dzieci poniżej 3 roku 
życia nie było objętych żadną formą opieki (najlepszy wynik po Danii - 26\%). Udział dzieci w różnych formach instytucjonalnej opieki wzrasta w UE i w Szwecji wraz Z wiekiem. Z 51\% dzieci poniżej 3 roku życia objętych opieką w krótszym lub dłuższym wymiarze udział ten wśród dzieci powyżej 3 lat wzrasta do 95\% i jedynie Belgia i Dania z udziałem 98\% osiągają korzystniejsze wyniki.

Rysunek 2. Udział dzieci w wieku 1-6 lat w formach opieki finansowanych przez władze lokalne w latach 1972-2011 (w \%)

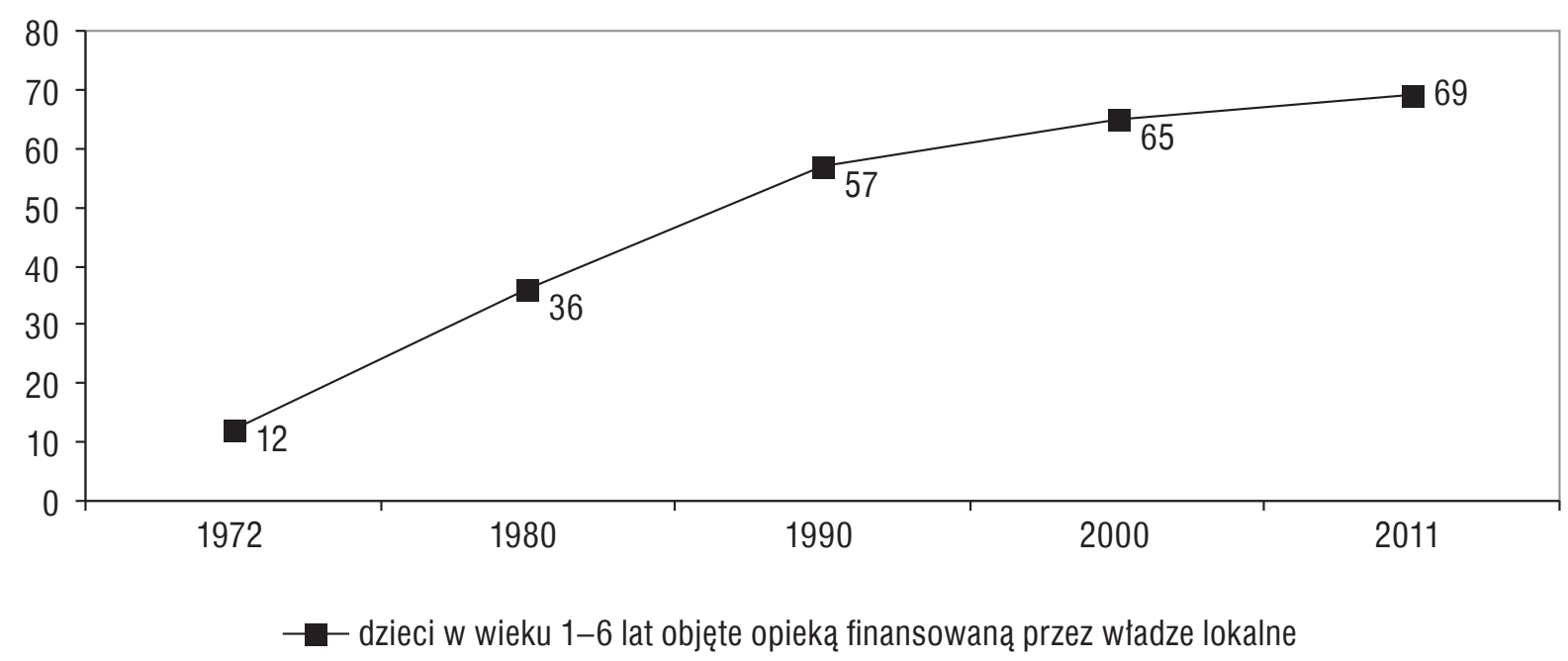

Źródło: Opracowanie własne na podstawie statystyki szwedzkiej: Women and man in Sweden, Facts and Figures 2012, Statistics Sweden 2012, s. 50.

Tabela 3. Udział dzieci $w$ różnych przedziałach wiekowych $w$ formalnej opiece w państwach członkowskich Unii Europejskiej w 2011 r. (w \%)

\begin{tabular}{|c|c|c|c|c|c|c|}
\hline & \multicolumn{3}{|c|}{$\begin{array}{c}\text { Dzieci poniżej } 3 \text { roku życia objęte formalną opieką } \\
\text { - udział w poszczególnych grupach }\end{array}$} & \multicolumn{3}{|c|}{$\begin{array}{c}\text { Dzieci pomiędzy } 3 \text { rokiem życia a wiekiem } \\
\text { rozpoczęcia obowiązkowego kształcenia objęte } \\
\text { formalną opieką - udział w poszczególnych } \\
\text { grupach }\end{array}$} \\
\hline & $\begin{array}{c}\text { nieobjęte } \\
\text { formalną } \\
\text { opieką }\end{array}$ & $\begin{array}{l}\text { objęte formalną } \\
\text { opieką } \\
\text { w wymiarze } \\
\text { od } 1 \mathrm{~h} \text { do } 29 \mathrm{~h} \\
\text { tygodniowo }\end{array}$ & $\begin{array}{l}\text { objęte formalną } \\
\text { opieką } \\
\text { w wymiarze } \\
\text { ponad } 30 \mathrm{~h} \\
\text { tygodniowo }\end{array}$ & $\begin{array}{c}\text { nieobjęte } \\
\text { formalną } \\
\text { opieką }\end{array}$ & $\begin{array}{l}\text { objęte formalną } \\
\text { opieką } \\
\text { w wymiarze } \\
\text { od } 1 \mathrm{~h} \text { do } 29 \mathrm{~h} \\
\text { tygodniowo }\end{array}$ & $\begin{array}{l}\text { objęte formalna } \\
\text { opieką } \\
\text { w wymiarze } \\
\text { ponad } 30 \mathrm{~h} \\
\text { tygodniowo }\end{array}$ \\
\hline UE-27 & 71 & 15 & 15 & 16 & 37 & 47 \\
\hline Austria & 86 & 11 & 3 & 15 & 57 & 28 \\
\hline Belgia & 62 & 19 & 20 & 2 & 32 & 66 \\
\hline Bułgaria & 93 & 0 & 7 & 41 & 2 & 58 \\
\hline Cypr & 77 & 7 & 16 & 27 & 35 & 38 \\
\hline Czechy & 95 & 4 & 1 & 26 & 29 & 45 \\
\hline Dania & 26 & 5 & 69 & 2 & 11 & 87 \\
\hline
\end{tabular}




\begin{tabular}{|l|l|r|r|r|r|l|}
\hline Estonia & 81 & 4 & 15 & 8 & 9 & 83 \\
\hline Finlandia & 74 & 6 & 20 & 24 & 20 & 57 \\
\hline Francja & 56 & 18 & 26 & 5 & 43 & 52 \\
\hline Grecja & 81 & 4 & 15 & 24 & 43 & 32 \\
\hline Hiszpania & 61 & 20 & 19 & 14 & 45 & 41 \\
\hline Holandia & 48 & 46 & 6 & 11 & 76 & 13 \\
\hline Irlandia & 79 & 10 & 11 & 18 & 68 & 14 \\
\hline Litwa & 92 & 1 & 6 & 35 & 9 & 56 \\
\hline Luksemburg & 57 & 16 & 28 & 27 & 46 & 27 \\
\hline Łotwa & 84 & 1 & 14 & 27 & 7 & 66 \\
\hline Malta & 89 & 8 & 3 & 27 & 29 & 44 \\
\hline Niemcy & 76 & 9 & 15 & 10 & 46 & 44 \\
\hline Polska & 97 & 0 & 3 & 56 & 9 & 34 \\
\hline Portugalia & 65 & 1 & 34 & 19 & 7 & 74 \\
\hline Rumunia & 98 & 1 & 1 & 59 & 30 & 11 \\
\hline Stowacja & 96 & 1 & 3 & 25 & 13 & 62 \\
\hline Słowenia & 63 & 3 & 34 & 8 & 11 & 81 \\
\hline Szwecja & 49 & $\mathbf{1 9}$ & $\mathbf{3 2}$ & $\mathbf{5}$ & $\mathbf{3 1}$ & $\mathbf{6 4}$ \\
\hline Węgry & 92 & 1 & 7 & 25 & 16 & 59 \\
\hline W. Brytania & 65 & 30 & 5 & 7 & 66 & 27 \\
\hline Włochy & 74 & 9 & 17 & 5 & 20 & 75 \\
\hline
\end{tabular}

Źródło: Opracowanie własne na podstawie danych Eurostatu: Formal child care by duration and age group, http://epp.eurostat.ec.europa.eu/tgm/table.do?tab=table\&init=1\&language=en\&pcode=tps00185\&plugin=1, dostęp 28.03.2014.

Rozwiązania dotyczące urlopów związanych z urodzeniem i wychowaniem dziecka, podobnie jak te w zakresie instytucjonalnej opieki nad dzieckiem, cechuje duży zakres różnych możliwości, a także wysoka elastyczność pozwalająca na ich wykorzystanie w różnym zakresie i w różnych momentach życia dziecka. Otwarte zasady przyznawania służą też ich powszechności - prawie każdy rodzic szwedzki korzysta z przysługujących mu uprawnień w zakresie urlopu rodzicielskiego ${ }^{36}$. Ich cechą jest też hojny wymiar finansowy, którego celem jest zrekompensowanie utraconych dochodów.

${ }^{36}$ A.-Z. Duvander, T. Lappegard, G. Andersson, op.cit., s. 47. Kwestią, która wymagałaby szerszego i oddzielnego omówienia, jest porównanie sytuacji właścicieli przedsiębiorstw z pracownikami najemnymi. Jeśli analizować stopień wykorzystania urlopów związanych z posiadaniem dzieci, to kobiety wykorzystują go w połowie mniejszym wymiarze, a mężczyźni o $1 / 3$ mniej. Zob. A transnational report. Creating innovative working arrangements through the support of public employment services for a better work life reconciliation, red. M. Fsadni, September 2009, http://etc.gov.mt/Resources/file/Resources/2009\%20-\%20Creating \%20Innovative\%20Working\%20Arrangements\%20Report_pdf.pdf, dostęp 28.03.2014, s. 80. 
W kontekście opieki nad dziećmi w Szwecji, z uwagi na szeroki zakres usług publicznych w tym zakresie, w literaturze nie pojawia się problem wcześniejszej dezaktywacji zawodowej, głównie kobiet, opiekujących się wnukami. Nie oznacza to, że dziadkowie nie uczestniczą w opiece. Przeciwnie, liczba wspierających dziadków jest większa niż w państwach, w których brakuje niezbędnej infrastruktury, niemniej pomoc ma mniejszy wymiar czasowy i jest dużo mniej regularna i intensywna ${ }^{37}$. W państwach nordyckich opieka dziadków stanowi uzupełnienie formalnej opieki, a jej nie zastępuje, jak np. w państwach Europy Południowej. O ile w Szwecji jedynie $2 \%$ dziadków sprawuje regularną opiekę nad dzieckiem, o tyle w Hiszpanii ten udział sięga $25 \%^{38}$. W Szwecji nie mamy zatem do czynienia z etatowymi dziadkami, którzy, by wesprzeć dzieci, rezygnują z pracy.

Obowiązek opieki nad osobami starszymi nie pojawia się jako stały element w opracowaniach poświęconych czynnikom wpływającym na poziom aktywności Szwedek na rynku pracy. Niemniej, mając na względzie problemy sygnalizowane w tym kontekście na polskim rynku pracy, które mogą ulec pogłębieniu, warto przyjrzeć się powodom, dla których ten aspekt w Szwecji nie stanowi problemu. Nie bez znaczenia są z pewnością czynniki kulturowe wskazane wcześniej, które determinują zarówno politykę w tym zakresie, jak i postawy członków rodziny względem siebie. To również wynik świadomej i konsekwentnej polityki zdrowotnej, w tym profilaktycznej, Sztokholmu, dzięki której Szwedzi i Szwedki osiągają jeden z najwyższych po Norwegii wskaźników życia w dobrym zdrowiu w porównaniu z 24 innymi państwami europejskim. Według danych za 2011 r. średnia długość życia w dobrym zdrowiu Szwedów wynosiła około 79 lat, a kobiet 80 . W Polsce wskaźniki te były o 6 lat niższe dla mężczyzn i 7 dla kobiet ${ }^{39}$. To z kolei sprzyja większej samodzielności i aktywności zawodowej ${ }^{40}$. Znajduje również odzwierciedlenie w liczbie osób korzystających z pomocy zapewnianej przez władze lokalne w podziale na wiek. W latach 2010-2011 jedynie 1\% kobiet i tyle samo mężczyzn żyjących w związkach w wieku 65-74 lata i 7\% i 4\% żyjących samotnie wymagało opieki. W wieku 75 lat wskaźniki te były już znacznie wyższe: $9 \%$ i $8 \%$ oraz $26 \%$ i $24 \%$ odpowiednio ${ }^{41}$. Niemniej czynnikiem kluczowym jest zapewnienie przez państwo powszechnych i dobrej jakości usług opiekuńczych. Szwecja koncentruje się na zinstytucjonalizowanej formie opieki zapewnianej w pierwszej kolejności w domu, zgodnie z zasadą, że wsparcie osób starszych

\footnotetext{
37 Zob. szerzej: C. Igel, M. Szydlik, Grandchild care and welfare state arrangements in Europe, „Journal of European Social Policy" 2011, No. 3.

38 Doing better for families, OECD 2011, s. 144-145, http://www.oecd-ilibrary.org/social-issues-migration-health/doing-better-for-families_9789264098732-en, dostęp 1.04.2014.

39 OECD Reviews of Health Care Quality: Sweden 2013, Raising standards, op.cit., s. 126.

40 Zob. szerzej: R. Bakalarczyk, Opieka nad seniorami..., op.cit., s. 110-111.

${ }^{41}$ Women and man in Sweden..., op.cit., s. 48.
} 
powinno się odbywać jak najbliżej ich lokalnego środowiska. Dodatkowo funkcjonuje wiele różnych rozwiązań w zakresie placówek opiekuńczych dostosowanych do różnych potrzeb i problemów osób starszych. Obok tego systemu wsparcie udzielane jest również przez członków rodzin w ramach nieformalnej opieki. Opiekunom tym przysługuje szereg świadczeń mających na celu wsparcie w wypełnianiu dodatkowych obowiązków. Szczegóły stosowanych instrumentów przedstawiono w tabeli 2.

System publiczny pokrywał zapotrzebowanie na wsparcie ponad 75\% Szwedów i Szwedek deklarujących taką potrzebę i nie miał sobie równych wśród państw członków OECD ${ }^{42}$. Jest on zdominowany przez zinstytucjonalizowane usługi opiekuńcze. Jedynie $8 \%$ osób w wieku 50 lat i więcej, które najczęściej wypełniają role opiekuńcze wobec osób starszych w rodzinach, deklarowało takie zadania w przypadku Szwecji i był to najniższy odsetek z 16 badanych państw (rysunek 3). Jednocześnie udział nieformalnej opieki, w związku z konsekwentną polityką państwa w tym zakresie, sukcesywnie rośnie ${ }^{43}$ i biorąc pod uwagę zmieniającą się sytuacją demograficzną, może w przyszłości mieć większy wpływ na aktywność zawodową kobiet.

Rysunek 3. Udział osób w wieku powyżej 50 roku życia i więcej deklarujących nieformalną opiekę nad starszym członkiem rodziny w 2007 r. (w \%)

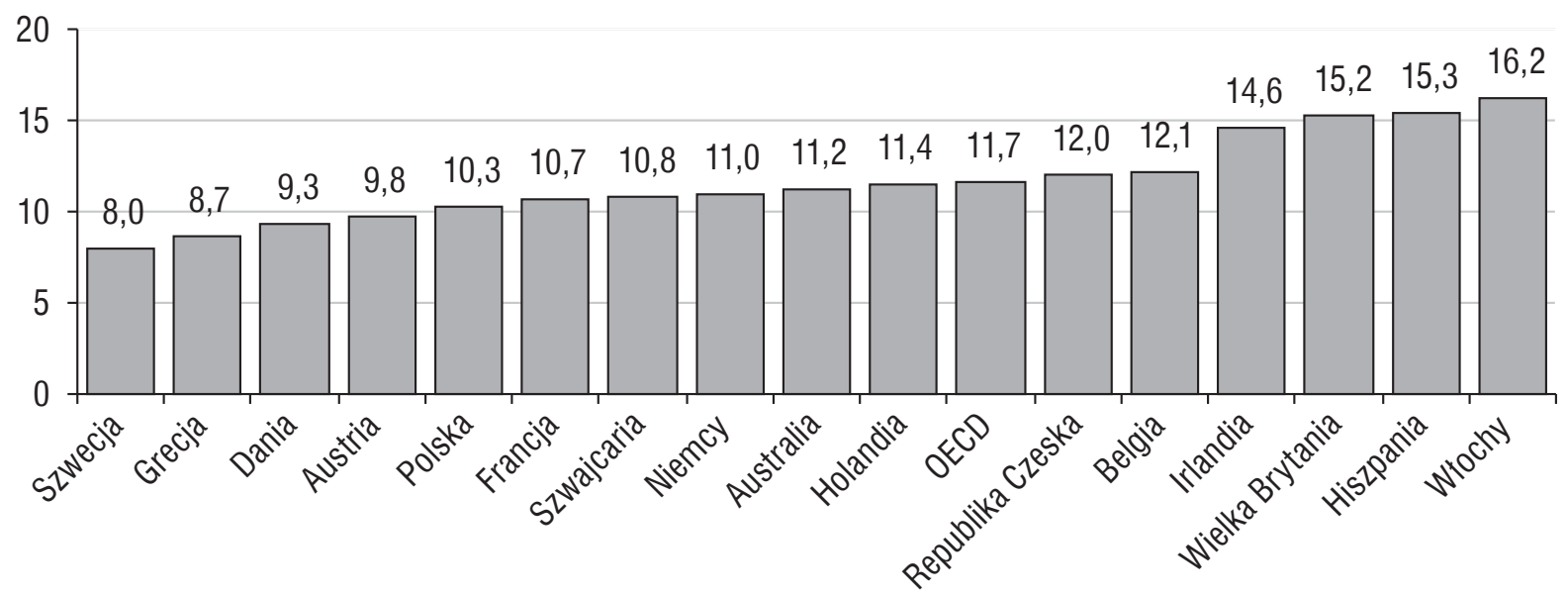

Źródło: Health at a glance: OECD Indicators, OECD 2011, http://www.oecd-ilibrary.org/sites/health_glance-2011-en/08/05/index.html?contentType $=\% 2 \mathrm{fns} \% 2 \mathrm{fChapter} \% 2 \mathrm{c} \% 2 \mathrm{fns} \% 2 \mathrm{fStatisticalPublication} \& \mathrm{itemId}=\% 2 \mathrm{f}$ content $\% 2$ fchapter\%2fhealth_glance-2011-70-en\&mimeType $=$ text $\% 2$ fhtml\&containerItemId $=\% 2$ fcontent $\% 2$ fserial\%2f19991312\&accessItemIds=, dostęp 1.04.2014.

${ }^{42}$ M. Księżopolski, Skuteczność modeli polityki społecznej w rozwiązywaniu problemów ludzi starych, „Problemy Polityki Społecznej. Studia i Dyskusje” 2012, nr 18, s. 34.

${ }^{43}$ Zob. szerzej: L. Johansson, G. Sundstrom, op.cit. 
W kontekście wszystkich instrumentów, którymi dysponuje Szwecja dla zapewnienia jak największej aktywności zawodowej kobiet, warto przyjrzeć się, jak każdy $\mathrm{z}$ nich, $\mathrm{w}$ świetle badań, wpływa na ten aspekt.

W opinii części badaczy czynniki odnoszące się do postaw (motywacji, aspiracji itd.) mają istotniejsze znaczenie w wyjaśnianiu tego, co wpływa na zatrudnienie kobiet, niż instytucjonalne czy strukturalne rozwiązania. W koncepcjach tych podkreśla się rosnące znaczenie wolnego wyboru co do modelu życia zawodowego oraz prywatnego i postępującej indywidualizacji w tym wyborze, które uwalniają ludzi ze strukturalnych ograniczeń. Jednocześnie na znaczeniu tracą tradycyjne czynniki, jak edukacja czy pochodzenie społeczne. Polemizując z tymi założeniami i opierając się na wcześniej wspomnianym badaniu International Social Survey Programme’s Family and Gender Relations Module, pogłębionym tym razem dla siedmiu nieco odmiennych państw (czterech nordyckich, Holandii, Niemiec i Wielkiej Brytanii), udowodniono, że choć postawy mają znaczenie, to nie można zgodzić się z twierdzeniem o nieistotności innych czynników i możliwości wolnego wyboru. Okazuje się bowiem, że czynniki o charakterze instytucjonalnym (dostępność zinstytucjonalizowanych form opieki, wymiar czasowy urlopów związanych z urodzeniem i wychowaniem dziecka itd.) również wpływają na podjęcie zatrudnienia przez kobiety, a ich wybór nie jest wolny od różnych uwarunkowań, jak chociażby opinii partnerów ${ }^{44}$. $\mathrm{Z}$ jednej strony $\mathrm{z}$ badań wynika, że istnieje powiązanie między poziomem postaw a zachowaniami na rynku pracy. Ogólna tendencja wskazuje, że postawy odgrywają większe znaczenie wśród osób niezatrudnionych niż w przypadku tych, które pracują. Niemniej przypadek szwedzki wyróżnia się w pewnym stopniu pod tym względem na tle badanych państw - w Szwecji osoby zatrudnione w niepełnym wymiarze czasu pracy cechuje największy wpływ postaw i to właśnie one stawiają opiekę nad rodziną na pierwszym miejscu, podczas gdy w innych państwach jest to typowa postawa dla osób niezatrudnionych. $\mathrm{Z}$ drugiej strony postawy te dodatkowo są determinowane czynnikami instytucjonalnymi ${ }^{45}$.

Istnieje powiązanie pomiędzy hojnymi urlopami związanymi z urodzeniem dziecka a zatrudnieniem w pełnymi i niepełnym wymiarze czasu pracy. Korzystne rozwiązania w tym zakresie zmniejszają liczbę osób pracujących w niepełnym wymiarze czasu pracy, a zwiększają szansę pełnego zatrudnienia w stosunku do braku pracy. Nie bez znaczenia jest również dostępność dobrej jakości i przystępnej cenowo oferty opieki nad dziećmi do 2 lat. Wpływa ona w sposób istotny na podjęcie zatrudnienia w pełnym wymiarze czasu, ma natomiast mało znaczący wpływ na zatrudnienie w niepełnym wymiarze. W przypadku form opieki nad dziećmi w wieku 3-6 lat zwiększają one szansę na zatrudnienie w każdej formie. Wśród innych czynników instytucjonalnych

44 O. Kangas, T. Rostgaard, Preferences or institutions? Work-family life opportunities in seven European countries, „Journal of European Social Policy” 2007, No. 3, s. 241, 253.

45 Ibidem, s. 245-246. 
autorzy wskazują liczbę dzieci, która zmniejsza szanse na pełne zatrudnienie, pracę w sektorze publicznym jako bardziej elastyczną w zakresie tworzenia miejsc pracy w niepełnym wymiarze czasu pracy czy status osoby samotnie wychowującej dziecko, który rzadziej wiąże się z niepełnym zatrudnieniem ${ }^{46}$.

Inne badania prowadzone w 14 państwach zachodnioeuropejskich, w których brano pod uwagę obowiązki opiekuńcze w stosunku do dzieci do lat 15 i osób starszych powyżej 65 lub 75 lat, wskazują, że rozwiązania w zakresie systemu opieki i stopień "outsourcingu” obowiązków domowych i rodzinnych mają wpływ na poziom zatrudnienia ${ }^{47}$. W badaniach analizowano systemy $\mathrm{z}$ uwzględnieniem pięciu wskaźników dotyczących urlopu rodzicielskiego, świadczeń pieniężnych związanych z posiadaniem dzieci (główne to ulgi podatkowe i świadczenia rodzinne), dostępności usług opiekuńczych dla dzieci, środków pieniężnych w dyspozycji osób starszych i podaży publicznych usług opieki nad osobami starszymi. Analiza wykazała, że systemy, które przypisują działania w zakresie opieki rodzinie, czyli nieformalnemu sektorowi, hamują zatrudnienie kobiet zarówno pod względem popytu, jak i podaży. Podczas gdy urynkowienie tych zdań czy ich wyprowadzenie poza rodzinę powoduje zmiany w jednym i drugim zakresie. Po stronie podaży pojawianie się substytutów nieformalnej opieki powoduje uwolnienie czasu, który może zostać poświęcony na podjęcie pracy zarobkowej. Natomiast po stronie popytu pojawiają się nowe miejsca pracy w sektorach związanych z zapewnieniem formalnej opieki, głównie dla kobiet (co wynika z silnej typologizacji zawodów ze względu na płeć) ${ }^{48}$.

Opinie co do wpływu urlopów związanych z urodzeniem dziecka na poziom zatrudnienia kobiet są podzielone. $Z$ jednej strony podkreśla się, że hojne urlopy pozwalają na zatrzymanie siły roboczej w związku z powrotem kobiety po urlopie na swoje stanowisko pracy. Ponadto dłuższy urlop stanowi wsparcie dla ciągłego powiązania z rynkiem pracy i zwiększa szanse na jego wykorzystanie również przez ojców, a w konsekwencji zmianę roli i zaangażowanie w wychowanie. Hojność finansowa urlopu wzmacnia bowiem dodatkowo taką postawę, a to wszystko wpływa na wcześniejszy powrót matek do pracy. Natomiast w państwach, w których ten urlop jest krótki lub nie rekompensuje dochodu, kobiety albo odkładają decyzję o dziecku, albo rezygnują z pracy. Podkreśla się również, że długa przerwa utrudnia powrót na rynek pracy ( $\mathrm{z}$ wyjątkiem osób z wyższym wykształceniem) i obniża dochody. W świetle badań optymalna długość urlopu to 20-24 tygodni. Do pewnego momentu wydłużanie urlopu powoduje większą skłonność kobiet do podjęcia

46 Ibidem, s. 248-249.

${ }^{47}$ F. Bettio, J. Plantenga, op.cit., s. 154.

48 Ibidem, s. 154-159, 165. 
zatrudnienia. Jednocześnie hojny urlop macierzyński może działać dyskryminująco po stronie pracodawców, jeśli analizuje się możliwość wejścia, głównie kobiet, na rynek pracy i w konsekwencji zmniejszać popyt na ich pracę $e^{49}$.

\section{Nierozwiązane problemy i wyzwania na przyszłość}

Pomimo wysokich wskaźników zatrudnienia szwedzkich kobiet nieporównywalnych z innymi państwami członkowskimi UE i istnienia wielu rozwiązań, w szczególności w zakresie polityki rodzinnej, sprzyjających godzeniu życia zawodowego z prywatnym, sytuacja kobiet na rynku pracy w Szwecji nie jest wolna od kolejnych wyzwań. Nierówności nadal istnieją w kontekście zatrudnienia, jego wymiaru czasowego i innych czynników. W szczególności podkreśla się takie ograniczenia szwedzkiego systemu w kształtowaniu sytuacji kobiet na rynku pracy, jak wysoki udziału zatrudnienia w niepełnym wymiarze czasu pracy, niski udział mężczyzn w urlopach rodzicielskich, wysoki udział w zatrudnieniu w sektorze publicznym, różnice w wynagrodzeniach oraz nierówny udział w nieodpłatnej pracy. W konsekwencji szwedzki system określany jest modelem 1 i 3/4, w którym mężczyźni pracują w pełnym wymiarze czasu pracy, robiąc karierę, a kobiety na niepełny etap, w miejscach gwarantujących bezpieczeństwo, ale kosztem niższej płacy $^{50}$. W wielu dziedzinach konieczna jest poprawa sytuacji, jednocześnie, jeśli przyjrzeć się sytuacji na tle innych państw, przypadek szwedzki wydaje się wskazywać na szerszy światowy kontekst problemów.

\subsection{Niepełny wymiar czasu pracy}

Problemem często wskazywanym w dyskusji dotyczącej skuteczności polityki rynku pracy adresowanej do kobiet w Szwecji jest ich wysoki udział w zatrudnieniu w niepełnym wymiarze czasu pracy. Ta tendencja stanowi cechę charakterystyczną państw Piętnastki (z wyjątkiem Grecji), podczas gdy w nowych państwach członkowskich jest dużo słabsza. W 2012 r. aż 38,6\% Szwedek z wszystkich zatrudnionych pracowało w niepełnym wymiarze czasu pracy w porównaniu z 12,5\% mężczyzn,

49 O. Kangas, T. Rostgaard, op.cit., s. 245; A. Kurowska, Ocena zasadności założeń reformy urlopów i zasiłków związanych z opieka nad małym dzieckiem, „Problemy Polityki Społecznej. Studia i Dyskusje” 2013, nr 21, s. 164; L. den Dulk, A. van Doorne-Huiskes, op.cit., s. 37-38; F. Bettio, J. Plantenga, op.cit., s. 161.

50 Gender and social policy in a global context: uncovering the gendered structure of "the social", red. S. Razavi, S. Hassim, United Nations Research, Institute for Social Development, Palgrave Macmillan, Houndmills 2006, s.10; B. Hobson, The evolution of the women-friendly state: opportunities and constraints in the Swedish welfare state, w: Gender and social..., ibidem, s. 160-165. 
co dawało Szwecji szóstą pozycję po Holandii (76,9\%), Niemczech (45\%), Austrii (44,4\%), Belgii (43,5\%) i Wielkiej Brytanii (42,3\%) i minimalnie przewyższało średnią dla państw Piętnastki. Jednocześnie Szwecja charakteryzowała się słabszymi różnicami w wyborze tej formy zatrudnienia pomiędzy mężczyznami i kobietami. Zróżnicowanie to było słabsze niż średnia dla 27 i 15 państw członkowskich - w tej ostatniej grupie aż 11 państw cechowało silniejsze zróżnicowanie (z wyjątkiem Danii, Grecji, Irlandii, Portugalii, Finlandii). Niemniej nadal Szwedki decydowały o skróceniu czasu pracy trzy razy częściej niż mężczyźni.

W kontekście argumentów o wypychaniu kobiet do tej formy zatrudnienia istotne jest, by przyjrzeć się również, na ile praca w niepełnym wymiarze była dla Szwedek i Szwedów kwestią ich wolnego wyboru, a na ile była determinowana czynnikami od nich niezależnymi. W świetle często pojawiających się argumentów co do tej drugiej opcji pewnym zaskoczeniem może być, iż w większości państw członkowskich UE, w tym w Szwecji, wybór zatrudnienia w niepełnym wymiarze czasu pracy nie $\mathrm{z}$ własnego wyboru dotyczy częściej mężczyzn niż kobiet, chociaż różnica jest niewielka. W 2012 r. 30,2\% mężczyzn i 28,3\% kobiet w Szwecji z ogółu mężczyzn i kobiet pracujących w niepełnym wymiarze czasu pracy deklarowało, że wybór ten nie odzwierciedlał faktycznych potrzeb. Tak mała różnica pomiędzy sytuacją kobiet i mężczyzn może dowodzić, że w tym państwie nie jest to problem determinowany przez płeć. Jeśli natomiast przyjrzeć się sytuacji w Szwecji na tle innych państw członkowskich i średniej dla całej Unii Europejskiej, zarówno w składzie 15, jak i 27 państw, to sytuacja mężczyzn jest minimalnie korzystniejsza niż kobiet [w przypadku mężczyzn Szwecja jest na trzynastej pozycji i poniżej średnich unijnych (UE-27: 38,5\%, UE-15: 37,7\%), a w przypadku kobiet na szesnastej i powyżej średnich unijnych (UE-27: 24,3\%, UE-15: 23,8\%)]. Jednocześnie do państw, w których problem ten był najsilniejszy, Szwecję dzieliło aż 42,8 pkt. proc. w przypadku mężczyzn (Włochy - 73\%) i 37,9 pkt. proc. w przypadku kobiet (Bułgaria - 66,2\%). Szczegóły przedstawiono w tabeli 4.

Wysoki udział procentowy osób pracujących w niepełnym wymiarze czasu w państwach Piętnastki spowodowany jest w pierwszej kolejności brakiem możliwości znalezienia zatrudnienia na pełen etat, przy czym problem ten w przypadku mężczyzn jest silniejszy niż kobiet (UE-15: ogółem - 26,8\%, mężczyźni - 37,7\%, kobiety - 23,8\%). Drugą przyczyną w przypadku kobiet jest konieczność opieki nad dzieckiem lub dorosłym członkiem rodziny (UE-15: kobiety - 21,7\%, mężczyźni - 4,3\%), a w przypadku mężczyzn inne powody niż uwzględnione w analizie (UE-15: kobiety - 19,6\%, mężczyźni - 22,8\%). Jednocześnie opieka nad dzieckiem czy innym członkiem rodziny - istotny czynnik świadczący o równym podziale obowiązków w życiu prywatnym - stanowi dla mężczyzn ostatni z wymienianych 
powodów pracy w niepełnym wymiarze czasu. Szwecja powiela w pełni te tendencje. Około 1/3 mężczyzn i kobiet w 2012 r. wskazywała na brak możliwości znalezienia innej formy zatrudnienia. Nieco mniej kobiet (ponad 1/5) zdecydowało się na pracę $\mathrm{w}$ niepełnym wymiarze czasu $\mathrm{z}$ uwagi na opiekę nad dzieckiem lub innym członkiem rodziny, w przypadku mężczyzn zadania w tym zakresie najsłabiej determinowały tę formę zatrudnienia (jedynie 7,8\%). W przypadku Szwedów (20,5\%) drugim powodem były inne czynniki niezdefiniowane w badaniu, które dla Szwedek $(17,8 \%)$ były na trzeciej pozycji. Istotne jest jednak, że kwestia opieki nie stanowi w Szwecji zasadniczego czynnika determinującego pracę na niepełny etat kobiet, a jest jedynie jednym z trzech powodów o podobnej wadze. Problem ten jest silniejszy dla średniej UE zarówno na poziomie 15 członków, jak i 27. Ważne jest również, iż w odróżnieniu od danych dla UE-15 opieka nad dzieckiem lub innym członkiem rodziny w przypadku kobiet w państwach UE-27 staje się głównym czynnikiem wpływającym na wybór zatrudnienia w niepełnym wymiarze czasu (28,4\%). Szczegóły przedstawiono na rysunku 4.

Tabela 4. Osoby pracujące w niepełnym wymiarze czasu i przymusowo podejmujące ten rodzaj zatrudnienia w podziale na płeć w 2012 r. w Unii Europejskiej (w \%)

\begin{tabular}{|c|c|c|c|c|c|c|}
\hline & \multicolumn{3}{|c|}{$\begin{array}{l}\text { Praca w niepełnym wymiarze czasu jako udział } \\
\text { w zatrudnieniu ogółem }\end{array}$} & \multicolumn{3}{|c|}{$\begin{array}{c}\text { Przymusowa praca w niepełnym wymiarze czasu } \\
\text { jako udział w zatrudnieniu w niepełnym wymiarze } \\
\text { czasu ogółem }\end{array}$} \\
\hline & \multicolumn{6}{|c|}{ osoby w wieku 15-64 lata } \\
\hline & ogółem & mężczyźni & kobiety & ogółem & mężczyźni & kobiety \\
\hline UE-27 & 19,2 & 8,4 & 32,1 & 27,6 & 38,5 & 24,3 \\
\hline UE-15 & 22,3 & 9,3 & 37,6 & 26,8 & 37,7 & 23,8 \\
\hline Austria & 24,9 & 7,8 & 44,4 & 10,1 & 13,8 & 9,3 \\
\hline Belgia & 24,7 & 9,0 & 43,5 & 9,5 & 14,0 & 8,4 \\
\hline Butgaria & 2,2 & 2,0 & 2,5 & 66,5 & 66,8 & 66,2 \\
\hline Cypr & 9,7 & 6,4 & 13,1 & 53,1 & 65,2 & 46,8 \\
\hline Czechy & 5,0 & 2,2 & 8,6 & 20,0 & 14,6 & 22,0 \\
\hline Dania & 24,8 & 14,8 & 35,8 & 17,5 & 13,8 & 19,2 \\
\hline Estonia & 9,2 & 5,1 & 13,2 & 20,2 & 18,4 & 20,8 \\
\hline Finlandia & 14,1 & 9,1 & 19,4 & 25,7 & 24,1 & 26,5 \\
\hline Francja & 17,7 & 6,4 & 30,0 & 31,5 & 38,3 & 29,9 \\
\hline Grecja & 7,6 & 4,7 & 11,8 & 65,0 & 69,9 & 62,2 \\
\hline Hiszpania & 14,6 & 6,5 & 24,4 & 60,9 & 69,3 & 58,2 \\
\hline Holandia & 49,2 & 24,9 & 76,9 & 9,1 & 12,9 & 7,8 \\
\hline Irlandia & 23,5 & 13,3 & 34,9 & 41,2 & 59,9 & 33,6 \\
\hline Litwa & 8,9 & 6,9 & 10,7 & 33,0 & 32,3 & 33,5 \\
\hline Luksemburg & 18,5 & 4,7 & 36,1 & 13,7 & 13,0 & 13,9 \\
\hline
\end{tabular}




\begin{tabular}{|l|r|r|r|r|r|r|}
\hline Łotwa & 8,9 & 6,7 & 11,0 & 43,5 & 45,2 & 42,5 \\
\hline Malta & 13,2 & 5,7 & 26,0 & 16,4 & 29,5 & 11,5 \\
\hline Niemcy & 25,7 & 9,1 & 45,0 & 16,6 & 26,6 & 14,4 \\
\hline Polska & 7,2 & 4,5 & 10,6 & 27,5 & 26,9 & 27,9 \\
\hline Portugalia & 11,0 & 8,2 & 14,1 & 47,9 & 41,7 & 51,9 \\
\hline Rumunia & 9,1 & 8,6 & 9,7 & 55,1 & 67,1 & 41,7 \\
\hline Stowacja & 4,0 & 2,8 & 5,5 & 32,1 & 35,4 & 30,0 \\
\hline Stowenia & 9,0 & 6,3 & 12,2 & 8,6 & 7,5 & 9,2 \\
\hline Szwecja & $\mathbf{2 5 , 0}$ & $\mathbf{1 2 , 5}$ & $\mathbf{3 8 , 6}$ & $\mathbf{2 8 , 8}$ & $\mathbf{3 0 , 2}$ & $\mathbf{2 8 , 3}$ \\
\hline Wegry & 6,6 & 4,3 & 9,3 & 41,1 & 45,2 & 38,9 \\
\hline W. Brytania & 25,9 & 11,5 & 42,3 & 19,4 & 37,5 & 13,9 \\
\hline Włochy & 16,8 & 6,7 & 31,0 & 58,8 & 73,0 & 54,5 \\
\hline
\end{tabular}

Źródło: Opracowanie własne na podstawie danych Eurostatu: Part-time employment as percentage of the total employment, involuntary part-time employment as percentage of the total part-time employment, http://epp. eurostat.ec.europa.eu/portal/page/portal/employment_unemployment_lfs/data/database, dostęp 10.03.2014.

Rysunek 4. Powody zatrudnienia w niepełnym wymiarze czasu pracy w podziale na płeć w Unii Europejskiej i w Szwecji w 2012 r. (w \%)

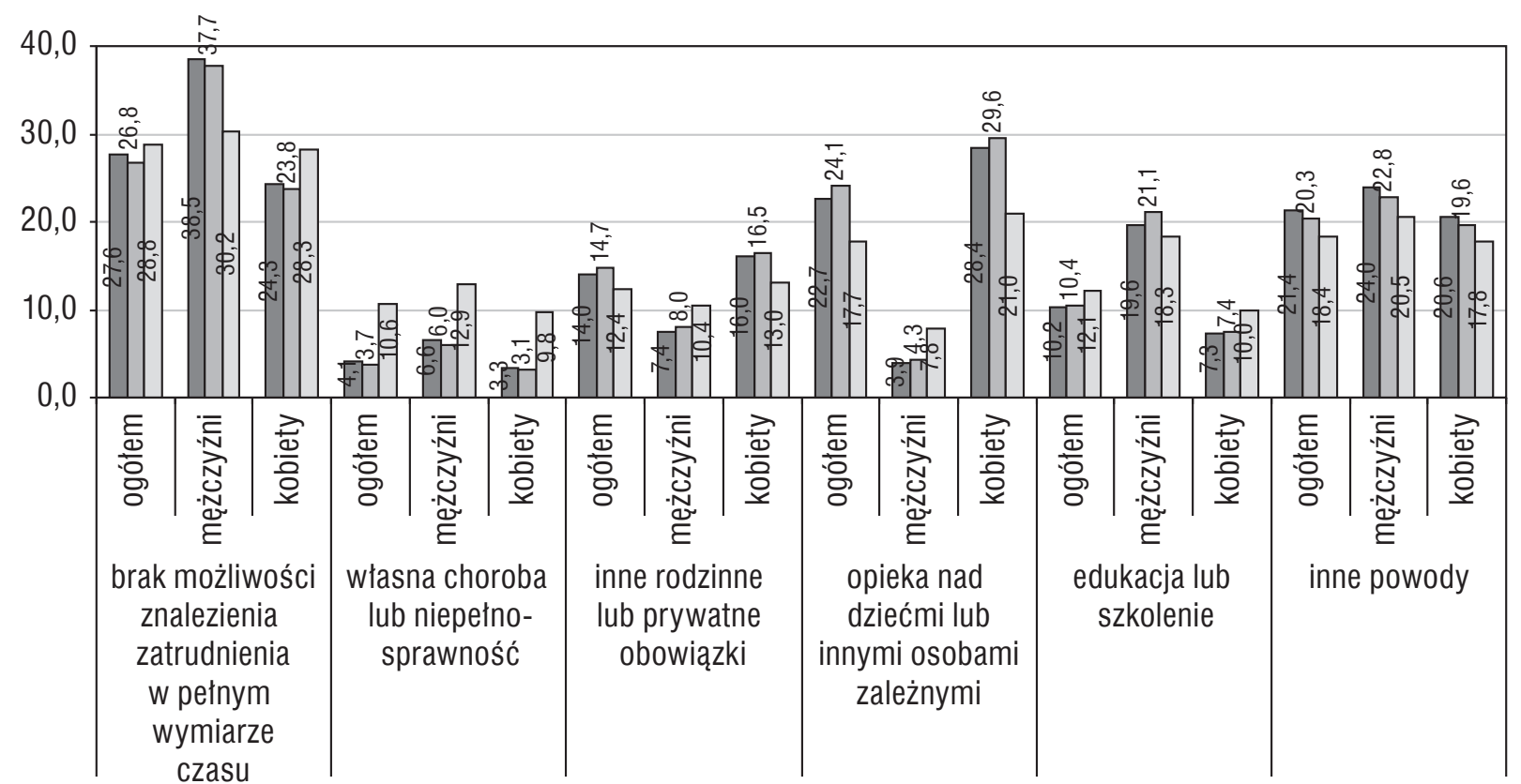

\section{UE-27 $\square$ UE-15 $\square$ Szwecja}

Źródło: Opracowanie własne na podstawie danych Eurostatu: Main reason for part-time employment, http:// appsso.eurostat.ec.europa.eu/nui/show.do?dataset=lfsa_epgar\&lang=en, dostęp 12.03.2014.

W żadnym państwie członkowskim opieka nad dzieckiem nie jest domeną mężczyzn. Niemniej, według danych na 2010 r., Szwecja, podobnie jak Estonia, jest bliska osiągnięcia stanu równowagi, jeśli brać pod uwagę liczbę osób, które zdecydowały 
się na zmniejszenie czasu pracy w związku z opieką nad dzieckiem poniżej 8 roku życia. W Szwecji około 200 tys. mężczyzn i około 250 tys. kobiet zdecydowało się na takie rozwiązanie. Jednocześnie nadal zdecydowanie więcej kobiet niż mężczyzn rezygnuje z pracy z powodów rodzicielskich (stosunek: około 8 tys. mężczyzn do około 180 tys. kobiet $)^{51}$.

Ocena zatrudnienia w niepełnym wymiarze czasu pracy w Szwecji nie jest jednoznaczna. W świetle niektórych badań elastyczność w stosowaniu tego instrumentu i zapewnienie dobrej jakości tego rodzaju miejsc pracy sprzyja powrotowi kobiet do pełnego zatrudnienia i bycia aktywnymi na rynku pracy ${ }^{52}$. Ta forma zatrudnienia stanowi również istotny instrument $\mathrm{w}$ polityce godzenia życia zawodowego z prywatnym $z$ uwzględnieniem cyklu życia i w Szwecji nie jest traktowana jako synonim niestabilności zatrudnienia, a bardziej jako wyraz stopniowego przejścia kobiet ze sfery prywatnej do zawodowej świadomie sterowanego przez władze publiczne od lat 60 . XX w., przy jednoczesnym wsparciu zatrudnienia w pełnym wymiarze czasu ${ }^{53}$. Co więcej, jest wspierana przez same kobiety, które często po urodzeniu dziecka opowiadają się za bardziej tradycyjnym modelem, nie kierując się jednak w podjęciu decyzji o przejściu na niepełny etat wysokością wynagrodzenia partnera, ale własną sytuacją finansową ${ }^{54}$. Z drugiej strony zwraca się uwagę na znaczący udział nisko płatnych miejsc pracy w niepełnym wymiarze, utrwalający silną segregację na rynku pracy, negatywny wpływ na kształtowanie kariery i rozwój zawodowy, a w konsekwencji ograniczenie skuteczności faktycznej długofalowej polityki równości płci ${ }^{55}$.

\subsection{Równy podział w wykorzystaniu urlopów rodzicielskich}

Udział mężczyzn w wykorzystaniu urlopów rodzicielskich rośnie od momentu ich wprowadzenia w $1974 \mathrm{r}$., niemniej nadal pozostaje na niskim poziomie ( $24 \%$ w 2011 r.) w porównaniu z wymiarem urlopu, z którego korzystają kobiety (rysunek 5).

${ }^{51}$ Persons who stopped work to care for their youngest child aged less than eight, persons who reduced their working time to care for their youngest child aged less than eight, 2010, Eurostat, http://epp.eurostat.ec.europa. eu/portal/page/portal/employment_unemployment_lfs/data/database, dostęp 10.03.2014.

52 Szerzej na temat badań w tym zakresie zob. E. Kenjoh, New mothers' employment and public policy in the UK, Germany, the Netherlands, Sweden, and Japan, „Labour Review of Labour Economics and Industrial Relations. Balancing Work and Child Care: the role of institutions" 2005, Vol. 19.

53 Zob. szerzej: D. Anxo, D. Storrie, op.cit., s. 49-63.

54 T. Korpi, Ch. Stern, op.cit., s. 123-124.

${ }^{55}$ R. Eklund, Sweden: part-time work - welfare or unfair?, w: Employment policy and the regulation of parttime work in the European Union: a comparative analysis, red. S. Sciarra, P. Davies, M. Freedland, Cambridge University Press, Cambridge 2004, s. 264-268, 294-295; Kobiety i mężczyźni na rynku pracy. Rzeczywistość lat 1990-1999, red. B. Balcerzak-Paradowska, D. Graniewska, B. Kołaczek, D. Głogosz, I. Hebda-Czaplicka, Warszawa 2001, s. 184, 205, 209-210. 


\section{Rysunek 5. Wykorzystanie urlopów rodzicielskich w podziale na płeć w latach 1974-2011 w Szwecji (w \%)}

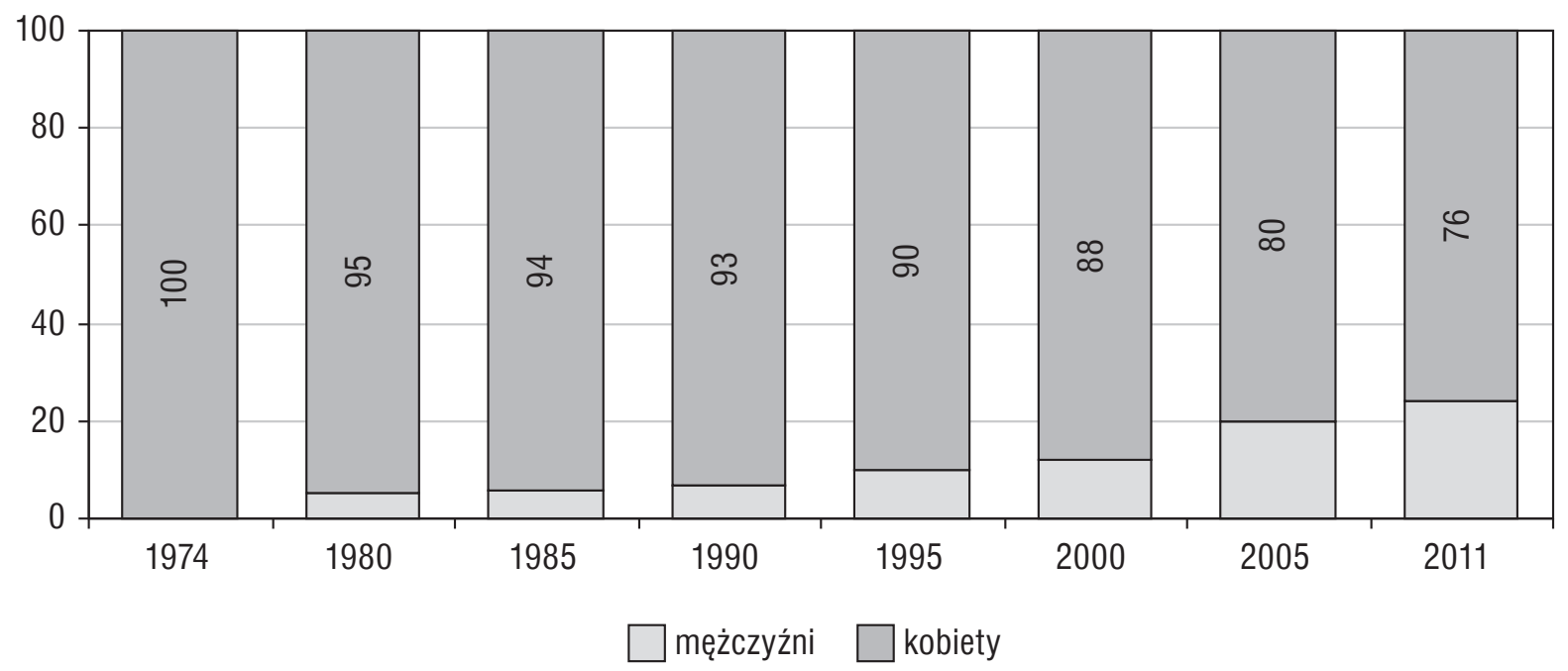

Źródło: Opracowanie własne na podstawie statystyki szwedzkiej: Women and man in Sweden..., op.cit., s. 43.

Jednocześnie w świetle badań powody, dla których ojcowie wykorzystują urlopy rodzicielskie, nie są związane z potrzebą zapewnienia równych szans płci na rynku pracy, choć w dalszej perspektywie mogą do tego prowadzić. Wynikają z przekonania o indywidualnych korzyściach, które mogą się pojawić. Kobiety też częściej decydują się na dłuższą przerwę niż mężczyźni. W latach 1988-1999 większość kobiet brała średnie i dłuższe urlopy (ponad 80\%), mężczyźni preferowali krótsze i średniej długości przerwy (ponad 72\%). Jednocześnie kobiety trzykrotnie (w przypadku 1 dziecka) i pięciokrotnie (w przypadku 2 dzieci) częściej decydowały się na bardzo długą przerwę ${ }^{56}$. Czynnikiem wpływającym na wykorzystanie urlopów zarówno w przypadku kobiet, jak i mężczyzn jest wykształcenie. Kobiety z niższym wykształceniem decydują się na dłuższe urlopy związane z urodzeniem dziecka, a wyższe wykształcenie mężczyzn zwiększa szansę na decyzję o wykorzystaniu urlopu ${ }^{57}$. Natomiast względy ekonomiczne wydają się mieć mniejsze znaczenie, choć tutaj nie ma zgodności poglądów $^{58}$. W przypadku mężczyzn lepiej zarabiających, dla których zmniejsze-

56 Women and man in Sweden..., op.cit., s. 22-49, 52.

57 I. Jönsson, op.cit., s. 143-145, 148.

58 Por. opinie wyrażane przez Konfederację Szwedzkich Firm. Zgodnie z ich badaniami opieka nad dzieckiem w przypadku obojga rodziców robiących karierę jest niemożliwa bez dezaktywacji jednego z nich, w szczególności mając na uwadze koszty zatrudnienia ewentualnej pomocy domowej w Szwecji. W związku z tym, że urlop rodzicielski nie stanowi odzwierciedlenia pełnego dochodu, a może być nawet niższy niż $80 \%$ dotychczasowych zarobków, osoba z niego korzystająca traci ponad 20\% środków, które miała do dyspozycji. W konsekwencji urlop bierze ten rodzic, który mniej zarabia i jest to najczęściej kobieta. Zob. A transnational report..., op.cit., s. 80 . 
nie dochodu w związku z urlopem jest bardziej odczuwalne, można zaobserwować częstsze decyzje o wykorzystaniu przerw w pracy $^{59}$.

\subsection{Praca płatna versus nieodpłatna}

Zgodnie z badaniami prowadzonymi przez OECD w latach 1999-2010 Szwedki nadal poświęcają więcej czasu na obowiązki domowe niż mężczyźni, przeznaczając na nieodpłatną pracę ponad godzinę więcej każdego dnia. Podobnie sytuacja wygląda w innych państwach skandynawskich. Jednocześnie jest o wiele bardziej pozytywna niż średnia dla państw OECD, w których ta różnica to ponad 2 godziny dziennie. Korzystniejszą sytuację w Szwecji w porównaniu z innymi państwami wiąże się $\mathrm{z}$ wysokim udziałem kobiet $\mathrm{w}$ zatrudnieniu i faktem, że wraz ze wzrostem ich zaangażowania $\mathrm{w}$ pracę zarobkową wzrasta zaangażowanie mężczyzn $\mathrm{w}$ pracę $\mathrm{w}$ gospodarstwie domowym ${ }^{60}$. Jednocześnie wraz $\mathrm{z}$ większą aktywnością zawodową kobiet rośnie ich siła negocjacyjna w relacjach rodzinnych, co z kolei może przekładać się na bardziej wyrównany podział obowiązków ${ }^{61}$.

Analizując ten problem $\mathrm{z}$ uwzględnieniem całościowego czasu poświęcanego przez kobiety i mężczyzn w Szwecji na wykonywanie pracy płatnej i niepłatnej od początku lat 90. XX w., udział bez względu na płeć jest zbliżony, niemniej mężczyźni od ponad 20 lat częściej pobierają za tę pracę wynagrodzenie. Jest to też kolejna konsekwencja wysokiego udziału pracy w niepełnym wymiarze czasu pracy kobiet, która powoduje, że kobiety spędzają w pracy zarobkowej dziennie około 5,5 godzin, a mężczyźni ponad 7 godzin. Przy czym zauważalna jest również inna zmiana w tendencji. Pomimo nadal mniejszego zaangażowania kobiet w pracę zarobkową od $1990 \mathrm{r}$. ich udział powoli rośnie (o 30 minut dziennie), a mężczyzn maleje (o 45 minut dziennie). Jednocześnie maleje czas poświęcany na pracę niezarobkową kobiet (o blisko godzinę) i bardzo nieznacznie wzrasta zaangażowanie w te zadania mężczyzn (o 8 minut) ${ }^{62}$.

Wart podkreślenia jest jednak fakt, że biorąc pod uwagę sytuację życiową osób w różnym wieku w latach 2010-2011, zauważalne są znaczne różnice. W parach bez dzieci w wieku 20-44 lata czas poświęcony na pracę nieodpłatną jest bardzo zbliżony bez względu na płeć. Natomiast widoczne jest również, że ilość nieodpłatnej pracy wzrasta wraz z pojawieniem się małych dzieci zarówno dla Szwedów, jak i Szwedek, niemniej kolejny raz wzrost ten jest silniejszy dla kobiet ${ }^{63}$. Zgodnie z badaniami OECD

\footnotetext{
59 Ibidem, s. 81.

60 Closing a gender gap. Act now, OECD 2012, s. 203, 259.

61 L. den Dulk, A. van Doorne-Huiskes, op.cit., s. 56.

62 Women and man in Sweden..., op.cit., s. 38-39.

63 Ibidem, s. 40.
} 
kobiety bowiem, z wyjątkiem Danii i Irlandii, gdzie podział ten jest mniej korzystny dla mężczyzn i identyczny (odpowiednio), dominują w zadaniach opiekuńczych. W Szwecji różnica na niekorzyść kobiet to 7 godzin tygodniowo ${ }^{64}$.

\subsection{Konsekwencje polityki w zakresie godzenia życia zawodowego z prywatnym dla funkcjonowania rodziny}

W dyskusjach nad instrumentami i skutecznością szwedzkiej polityki w zakresie wspierania zatrudnienia aktywności zawodowej kobiet pojawiają się również kwestie, które w przyszłości mogą spowodować zmiany w funkcjonowaniu całego społeczeństwa ${ }^{65}$. Jednocześnie należy podkreślić, że są to zagadnienia, w których przypadku pogłębione badania pozwalające na ostateczne wnioski i ewentualną korektę polityki nie są prowadzone.

Wśród potencjalnych problemów wskazuje się głównie na przeobrażenia w strukturze rodziny wpływające na jej niestabilność. Szwecja jest państwem o wysokim wskaźniku rozwodów - w $2012 \mathrm{r}$. kształtował się on na poziomie 2,5 (najniższy występował w Słowenii - 1,2, a w Polsce - 1,7). Cechą charakterystyczną jest również wysoki odsetek dzieci $(54,5 \%)$ przychodzących na świat w związkach pozamałżeńskich. Dla porównania państwem o najniższym udziale była Grecja - 7,6\%, a w Polsce odsetek ten kształtował się na poziomie 22,3\%. Charakterystyczne dla Szwecji było to, że zarówno pod względem liczby rozwodów, jak i dzieci w związkach pozamałżeńskich tendencje mają dosyć trwały charakter, nie zmieniając się w sposób zasadniczy od $2001 \mathrm{r}^{66}$

Chociaż badania wskazują na pozytywny wpływ wykorzystania przez mężczyzn urlopu rodzicielskiego na zmniejszenie liczby rozwodów, a Szwecja, jak wskazano wcześniej, prowadzi konsekwentną politykę w tym zakresie, przy jednoczesnym wzroście stopnia wykorzystania przerw w pracy przez Szwedów, pozostaje to bez znaczącego wpływu na liczbę małżeństw decydujących się na rozstanie. Jako główne powody wskazuje się przekonanie szwedzkiego społeczeństwa, że poziom równości nadal nie jest wystarczający oraz łatwość procedur prawnych w tym zakresie ${ }^{67}$.

\footnotetext{
${ }^{64}$ Closing a gender gap. Act now, op.cit., s. 259.

65 Por. I. Wieczorek, Programy kształtowania równowagi praca - życie: doświadczenia szwedzkie, w: Programy kształtowania równowagi praca - życie w organizacjach, red. P. Bohodziewicz, „Acta Universitatis Lodziensis, Folia Oeconomica” 2010, z. 240, s. 69-70; B. Balcerzak-Paradowska, op.cit., s. 31-34.

${ }^{6}$ Divorces, Live births outside marriage, Eurostat, http://epp.eurostat.ec.europa.eu/portal/page/portal/population/data/main_tables, dostęp 3.04.2014.

67 M. Kocik, op.cit., s. 101.
} 


\subsection{Gender pay gap}

Według danych OECD w 2011 r. wynagrodzenia kobiet były w Szwecji o 14\% niższe od wynagrodzeń mężczyzn i od lat wskaźniki te są mniej korzystne dla Sztokholmu niż np. państw śródziemnomorskich ${ }^{68}$ i jedynie o $1 \%$ niższe niż średnia dla państw OECD. Jednocześnie nie widać znaczących zmian od 2000 r., co świadczy o dużej trwałości tego zjawiska. Istotne jest również, że różnica w wynagrodzeniach wzrasta do $21 \%$ w przypadku osób posiadających dzieci, co częściowo może wynikać, jak wcześniej wspomniano, z dużego udziału kobiet w zatrudnieniu w niepełnym wymiarze czasu pracy. Jest ona również większa w wyższych przedziałach płacowych ${ }^{69}$.

Istotną przyczyną tego problemu może być silna segregacja horyzontalna polegająca na feminizacji niektórych sektorów zatrudnienia, głównie publicznego, co w znacznej mierze jest też konsekwencją zinstytucjonalizowania części usług wraz ze zwiększeniem aktywności zawodowej kobiet. W 2010 r. ponad 91\% kobiet w Szwecji pracowało w usługach w porównaniu z 66\% mężczyzn, a jedynie 7,6\% w przemyśle, czyli ponad cztery razy mniej niż mężczyzn. Szwedki dominowały w takich sektorach jak: administracja publiczna (55\% zatrudnionych), edukacja (74,6\%), zdrowie i pomoc społeczna $(83,4 \%)^{70}$. Silna segregacja zawodowa powoduje, że przy istnieniu tak dużego sektora publicznego, jakim cechuje się Szwecja, kobiety tkwią w gałęziach gospodarki, które nie gwarantują im wyższych dochodów ${ }^{71}$.

Szwecji nie jest również obcy problem segregacji wertykalnej, choć w tym przypadku sytuacja jest bardziej zróżnicowana. Szwedki w 2010 r. stanowiły jedynie 31\% starszej kadry zarządzającej w sektorze prywatnym, a tylko 19\% z nich było członkami zarządów w 2009 r. I choć Szwecja pod względem tego drugiego wskaźnika była drugim państwem o najwyższym udziale, to do lidera, Norwegii, brakowało jej kolejnych 19\%. Jednocześnie w kadrach zarządzających administracji centralnej kobiety stanowiły $40 \%$ zatrudnionych ${ }^{72}$. W porównaniu $\mathrm{z}$ sektorem prywatnym wynik ten stanowi o znacznej różnicy, niemniej, zważywszy na dominację kobiet w tym sektorze, należy go raczej odczytywać w kategoriach niewystarczającej reprezentacji. Według

${ }^{68} \mathrm{~W}$ tym przypadku może to wynikać z częstszego zatrudnienia w pełnym wymiarze czasu. Zob. L. den Dulk, A. van Doorne-Huiskes, op.cit., s. 53-54.

${ }^{69}$ Closing a gender gap. Act now, op.cit., s. 166-172. Dodatkowo problem,,szklanego sufitu" cechujący szwedzki rynek pracy w wyższych przedziałach płacowych omówiono szczegółowo w: J. Albrecht, A. Bjorklund, S. Vroman, Is there a glass ceiling in Sweden?, "Journal of Labour Economics” 2003, No. 1.

70 Closing a gender gap. Act now, op.cit., s. 240, 244.

71 O. Kangas, P. Palme, Coming late - catching up: the formation of a „Nordic Model”, w: Social policy and economic development in the Nordic countries, red. O. Kangas, P. Palme, Palgrave Macmillan, Houndmills, Basingstoke, New York 2005, s. 37-38.

72 Closing a gender gap. Act now, op.cit., s. 177-193, 259. 
innych wcześniejszych badań to nie w państwach modelu socjaldemokratycznego znaleźć można najwięcej kobiet na stanowiskach zarządzających, ale w Irlandii, Wielkiej Brytanii, Francji, Portugalii i kilku państwach postsocjalistycznych. Jeśli jednak wziąć pod uwagę bardziej szczegółowe kryteria odnoszące się do poziomu zarobków czy sprawowanej władzy, to różnice zmniejszają się w znaczny sposób. Ograniczając analizę wyłącznie do wyższych stanowisk w sektorze prywatnym, na poziomie wszystkich badanych państw pojawiają się większe różnice ze względu na płeć, a sytuacja zdecydowanie korzystniej wygląda ponownie w państwach skandynawskich. W tym przypadku model państwa nie ma większego wpływu na liczbę kobiet na stanowiskach zarządzających ogółem, jest natomiast istotnym czynnikiem, gdy ograniczymy analizę do wyższych stanowisk zarządczych ${ }^{73}$.

\section{Podsumowanie}

Powracając do pierwszej części pytania postawionego na wstępie artykułu co do sposobu, w jaki Szwecji udało się osiągnąć najwyższe w Unii Europejskiej wskaźniki zatrudnienia kobiet, jako kluczowy należy wskazać szwedzki model państwa, który wzmacnia szanse kobiet na zatrudnienie. Czyni to poprzez odpowiednie ramy prawne i strategiczne, a także rozwiązania instytucjonalne. Tym procesom sprzyjają wzorce postaw i preferencji, którymi kieruje się szwedzkie społeczeństwo. Istotne jest jednak, że te trzy elementy wzajemnie się przenikają i tylko w ich powiązaniu wydaje się możliwe osiągnięcie porównywalnej do Szwecji aktywności zawodowej kobiet.

Większość kwestii wskazanych jako problemowe stanowi wyzwanie nie tylko dla Szwecji, ale także poza nią, a ich jednoznaczna ocena jako zjawisk negatywnych wymyka się często prostej argumentacji. Nierzadko bowiem wyzwania te są niejako ubocznym skutkiem wieloletniej i świadomej polityki, której przyświecało wsparcie kobiet $\mathrm{w}$ ich aktywności zawodowej. I nawet jeśli cel ten został osiągnięty, to zrodził nowe problemy. Przykładem jest wysoki udział kobiet w zatrudnieniu w niepelnym wymiarze czasu pracy, który z jednej strony utrzymuje kobiety w aktywności zawodowej, z drugiej umacnia segregację na rynku pracy i nie pozwala na ich wyjście z zawodów gorzej opłacanych. Jest to też problem, w którego przypadku polityka państwa mająca na celu zwiększenie udziału kobiet w zatrudnieniu w niektórych sytuacjach może przeczyć faktycznym preferencjom kobiet. Są to też problemy często głęboko zakorzenione zarówno w praktyce, jak i w złożonych strukturach,

${ }^{73}$ L. den Dulk, A. van Doorne-Huiskes, op.cit., s. 53-55. 
w których przypadku procesy zmian zachodzą niezwykle powoli. Wszystko to nie oznacza, że problemy nie istnieją i że można je zlekceważyć, niemniej tak jak Szwecja potrzebowała blisko 30 lat, by stać się liderem pod względem wskaźników aktywności zawodowej kobiet, osiągniętym głównie poprzez zapewnienie odpowiedniej infrastruktury opieki nad osobami zależnymi, podobnie dla wprowadzenia bardziej złożonych instrumentów pozwalających likwidować identyfikowane obecnie bariery będzie potrzebowała więcej czasu.

\section{Employment of women in Sweden: reason for high employment rate and future concerns}

For many years Sweden remained a world leader in the employment of women, regardless of their age and responsibilities associated with raising children or caring for the elderly. This article analyses three groups of factors that influence the effectiveness of the Swedish policy in this regard: 1) strategic, i.e. the consistent and coherent policy on equal opportunities for women and men and the reconciliation of work and private life, 2) cultural attitudes and preferences that shape the behaviour of individuals in the family and on the labour market, and 3) institutional, particularly care of dependent persons. The picture would be incomplete, however, without looking at the problems remaining to be solved in such areas as high proportion of women in part-time work, the pay gap or insufficient interest of men in using parental leave.

Keywords: activity of women on the labour market, unemployment of women, gender equality, Sweden

\section{Les conditions de travail des femmes en Suède: les raisons d'un taux d'emploi élevé et les préoccupations futures}

Pendant de nombreuses années, la Suède demeure_un leader_mondial concernant l'emploi des femmes, indépendamment de leur âge et de leurs responsabilités associées à l'éducation des enfants ou de soins aux personnes âgées. Cet article analyse trois groupes de facteurs qui influent sur l'efficacité de la politique suédoise à cet égard: 1) les facteurs stratégiques, à savoir la politique cohérente sur l'égalité des chances pour les femmes et les hommes et la conciliation du travail et de la 
vie privée, 2) les attitudes culturelles et les préférences qui façonnent le comportement des individus dans la famille et sur le marché du travail, et 3) les facteurs institutionnels, en particulier les soins des personnes dépendantes. Cependant, l'auteur présente également les problèmes qui restent à résoudre dans les domaines tels que l'emploi partiel des femmes, l'écart de rémunération et le congé parental peu utilisé par les hommes.

Mots-clés: l'activité des femmes sur le marché du travail, le chômage des femmes, l'égalité des sexes, la Suède

\section{Шведки на рынке труда - условия для их высокой экономической активности и задачи на будущее}

На протяжении многих лет Швеция остается лидером в отношении уровня занятости женщин, независимо от их возраста и обязанностей, связанных с воспитанием детей или уходом за пожилыми людьми. Статья посвящена анализу трех групп факторов, влияющих на эффективность шведской политики в этой области. Они касаются следующих вопросов: 1) стратегических, т. е. последовательной и согласованной политики по обеспечению равных возможностей женщин и мужчин и сочетания работы и личной жизни; 2) культурных традиции и предпочтений, которые формируют поведение индивидов в семье и на рынке труда; и 3) институциональных в области ухода за зависимыми людьми. Тем не менее, картина была бы неполной, если не взглянуть на проблемы, которые еще предстоит решить в таких областях как высокая доля женщин занятых неполный рабочий день, разрыв в оплате труда или недостаточная заинтересованность мужчин в использовании родительского отпуска.

Ключевые слова: активность женщин на рынке труда, безработица среди женщин, равенство полов, Швеция 